\title{
Thrombin Stimulated Platelet-Derived Exosomes Inhibit Platelet-Derived Growth Factor Receptor-Beta Expression in Vascular Smooth Muscle Cells
}

\author{
Ming Tan ${ }^{a}$ Hong-Bing Yan ${ }^{a}$ Jian-Nan Li ${ }^{a}$ Wen-Ke Lib Yuan-Yuan Fu ${ }^{b}$ Wen Chen \\ Zhou Zhoub \\ aState Key Laboratory of Cardiovascular Disease, Fuwai Hospital, National Center for Cardiovascular \\ Diseases, Chinese Academy of Medical Sciences and Peking Union Medical College, Beijing, \\ bState Key Laboratory of Cardiovascular Disease, Beijing Key Laboratory for Molecular Diagnostics \\ of Cardiovascular Diseases, Diagnostic Laboratory Service,Fuwai Hospital, National Center for \\ Cardiovascular Diseases, Chinese Academy of Medical Sciences and Peking Union Medical College, \\ Beijing, People's Republic of China
}

\section{Key Words}

Atherothrombosis - Platelet • Exosome - MicroRNA • Smooth muscle cell • Platelet-derived growth factor receptor-beta

\begin{abstract}
Background/Aims: It is difficult to predict acute thrombotic cardiovascular events in the clinic. Few studies have reported the presence of plasma exosomes containing microRNAs (miRNAs) in cardiovascular events. Therefore, we aimed to investigate the levels of miR-223, miR-339 and miR-21 in plasma exosomes before thrombosis in mouse models of carotid tandem stenosis, as well as the mechanisms underlying the origin and function of these exosomal miRNAs. Methods: Plasma samples were collected from the carotid tandem stenosis and sham control groups of our successfully developed atherothrombosis mouse models before thrombosis. Platelets from healthy volunteers and mice were purified to obtain thrombin stimulated platelet-derived exosomes. Exosomes were isolated via differential ultracentrifugation, and western blotting and transmission electron microscopy were used for their identification. The total RNA was extracted, and quantitative real-time PCR was performed to determine the expression levels of miR-223, miR-339 and miR-21. DAVID Tools were used to analyze the pathways that were enriched among the miRNA target genes. Immuno-fluorescence staining was performed to identify the protein expression levels of platelet-derived exosome target genes in vascular smooth muscle cells (SMCs) in vitro and in vivo. Results: The levels of miR-223, miR-339 and miR-21, which are associated with platelet activation, were elevated in pooled mouse plasma exosomes before thrombosis and enriched in thrombin-stimulated platelet-derived exosomes in vitro. Platelet-derived growth factor receptor-beta (PDGFR $\beta$ ) was

Hong-Bing Yan
and Zhou Zhou

KARGER

State Key Laboratory of Cardiovascular Disease, Fuwai Hospital, National Center for

Cardiovascular Diseases, Chinese Academy of Medical Sciences and Peking Union

Medical College, No.167, North Lishi Road, Beijing, 100037 (China)

E-mail hbyanfuwai@aliyun.com (HB Yan) / zhouzhou@fuwaihospital.org (Z Zhou)
\end{abstract}




\section{Cellular Physiology Cell Physiol Biochem 2016;38:2348-2365 \\ \begin{tabular}{ll|l} 
DOI: 10.1159/000445588 & $\begin{array}{l}\text { () } 2016 \text { The Author(s). Published by S. Karger AG, Base } \\
\text { www.karger.com/cpb }\end{array}$ \\
\hline
\end{tabular} \\ Tan et al.: Platelet-Derived Exosomes as a Biomarker for Predicting Atherothrombosis}

a target of these miRNAs, and PDGFR $\beta$ expression in vascular smooth muscle cells (SMCs) was inhibited following incubation with platelet-derived exosomes. Platelet-derived exosomes could also inhibit PDGF-stimulated SMC proliferation. Furthermore, a decrease in PDGFR $\beta$ expression was observed in vascular SMCs around thrombotic areas in vivo. Conclusions: Our data indicate that activated platelet-derived exosomes containing miR-223, miR-339 and miR21 could be transferred into SMCs and inhibit PDGFR $\beta$ expression; these exosomal miRNAs may be a biomarker for predicting atherothrombosis.

\section{Introduction}

Thrombosis in coronary arteries is the major cause of acute coronary syndrome (AC

S) and sudden cardiac death [1]. Thrombotic complications are the most dreaded clinical consequences of atherosclerosis, but they are often unpredictable [2]. Previous studies focusing on the prediction of thrombotic events in atherosclerosis showed that vulnerable coronary plaque caused less than $10 \%$ of ACS cases in a three-year follow-up [3]. Circulating biomarkers of inflammation and coagulation activities may be of potential value in predicting these events $[2,4]$. Thrombin activity is a significant risk factor for thrombosis [5], and thrombin generation at the site of vascular injury in ACS patients also served as a potent platelet agonist [6]. Some studies supported the hypothesis that large, dense, reactive platelets play a causal role in ACS [7]. Therefore, studies focusing on factors that reflect platelet activation may provide a way to facilitate predictions of ACS.

An appropriate animal model that reflects human atherothrombosis will provide important information that will improve our understanding of ACS. Previously published studies showed that many plaques rupture and that plaque instability is present in animal models [8-10]. It seems that low shear stress and high tensile stress are both important determinants that are responsible for atherosclerotic plaque rupture and thrombosis [11, 12]. The present study performed carotid artery tandem stenosis surgery to introduce atherothrombosis [10]. Blood samples were taken before thrombosis, and plasma exosomes were isolated to analyze microRNAs (miRNAs).

The platelet is an anucleate cell without genomic DNA, but it contains an abundance and diverse array of messenger RNAs (mRNAs) and miRNAs [13]. Multiple functional aspects of miRNAs and their expression in platelets have been noted during platelet biogenesis and activation [14, 15]. Previous studies reported that miR-223, miR-339 and miR-21 were all enriched in platelets and associated with platelet activation $[16,17]$. The exosome is a type of extracellular vesicle that is as small as $100 \mathrm{~nm}$ in diameter, and it originate from endosomal compartments by fusion of multi-vesicular bodies with the plasma membrane [18]. The presence of exosomes containing miRNAs in plasma has received increasing attention as a novel biomarker for cardiovascular disease [19]. Different agonists stimulate platelets to release microvesicles and exosomes [20], which may contribute to $25 \%$ of the total number of extracellular vesicles (EVs) in blood [21]. Ago2-miR-223 can be delivered to endothelial cells via microvesicles that are released from activated platelets [22], and platelet-derived exosomes can induce endothelial cell apoptosis [23]. However, few studies have reported the signature of thrombin-stimulated platelet-derived exosomes and their function on vascular SMCs.

Vascular SMCs are the major component of the vascular wall and endure both ongoing damage and repair during atherosclerosis [24]. During repair, newly migrated SMCs tend to have more division defects and frequently undergo apoptosis [25]. In addition, SMC apoptosis in advanced coronary lesions has been associated with unstable angina [26]. Therefore, it is important to discover the role of thrombin-stimulated platelet-derived exosomes in vascular SMCs.

In this study, we investigated the changes in plasma exosomal miR-223, miR-339 and miR-21 expression before thrombosis in atherothrombosis mouse models and in activated 


\section{Cellular Physiology Cell Physiol Biochem 2016;38:2348-2365 \\ \begin{tabular}{ll|l} 
and Biochemistry & $\begin{array}{l}\text { DOI: 10.1159/000445588 } \\
\text { Published online: May 23, } 2016\end{array}$ & $\begin{array}{l}\text { ( ) 2016 The Author(s). Published by S. Karger AG, Basel } \\
\text { www.karger.com/cpb }\end{array}$ \\
\hline
\end{tabular} \\ Tan et al.: Platelet-Derived Exosomes as a Biomarker for Predicting Atherothrombosis}

platelet-derived exosomes. Second, we investigated the effects of target genes of miRNAs containing in platelet-derived exosomes on vascular SMCs in vitro and in vivo.

\section{Materials and Methods}

Atherothrombosis mouse model

Animal experiments were approved by the Fuwai Hospital Animal Care and Use Committee. Male ApoE-knockout (ApoE-/-) C57BL/6J mice were obtained commercially from Vital River Company, China. A total of 55 mice were used in this study and allocated to the $150 \mu \mathrm{m}$ tandem stenosis group $(\mathrm{n}=40)$ and sham surgery group $(n=15)$. Six-week-old mice were randomly assigned to one of these groups. The mice were housed in a climate-controlled environment and fed a western diet containing $21 \%$ fat and $0.15 \%$ cholesterol (Research Diet, America) for 6 weeks before surgery. Each mouse was anesthetized with an intraperitoneal injection of $0.6 \%$ sodium pentobarbital $(0.1 \mathrm{ml} / 10 \mathrm{~g}$ weight $)$ to minimize discomfort before surgery. An incision was made in the neck, and the right common carotid artery was dissected from the surrounding connective tissue. A stenosis with a $0.15 \mathrm{~mm}$ outer diameter was introduced, with the distal point at $1 \mathrm{~mm}$ from the carotid artery bifurcation and the proximal point at $3 \mathrm{~mm}$ from the distal stenosis. After surgery, the mice were fed a western diet for seven weeks and then sacrificed.

\section{Tissue processing and immunohistochemistry}

Each mouse was anesthetized using sodium pentobarbital. After a blood sample was collected, a catheter was placed in the left ventricle for perfusion with $10 \mathrm{ml}$ of PBS for 5 minutes, followed by $10 \mathrm{ml}$ of $10 \%$ formalin. After perfusion, the right common carotid artery was collected, immersed in formalin for 24 hours, and then embedded in paraffin. Six micrometer thick cross-section slides were prepared using a microtome (Leica RM2235). The slides were stained with hematoxylin/eosin (HE). The paraffin sections were rehydrated, and then antigen retrieval was performed in sodium citrate buffer, $\mathrm{pH}$ 6.0, in an autoclave for 2.5 minutes. Specimens were blocked for 60 minutes, and then incubated with primary antibodies overnight at $4^{\circ} \mathrm{C}$. The primary antibodies included anti-alpha smooth muscle actin (1:1000, Abcam) and anti-PDGF receptor (1:1000, CST). Images were captured using a laser scanning confocal microscope (LMS780, Carl Zeiss) with a $20 \times$ objective in LineSequential scan mode and an image size of $1024 \times 1024$. Zen 2012 blue edition (Carl Zeiss) was used to analyze the images.

\section{Preparation of pure mouse and human platelets}

Blood was withdrawn from inferior vena cava of a wild type (WT) C57BL/6J mouse (vital river company, China) into a syringe containing $150 \mu \mathrm{l}$ of acid citrate dextrose (ACD, $85 \mathrm{mM}$ sodium citrate, 111 $\mathrm{mM}$ glucose, and $71 \mathrm{mM}$ citric acid) through a $22 \mathrm{G}$ needle and gently mixed. The blood was centrifuged at $200 \mathrm{~g}$ for 12 minutes at room temperature without braking, and less than $60 \%$ of the platelet-rich plasma was aspirated into a new tube. Platelets were pelleted by centrifugation at $900 \mathrm{~g}$ for 12 minutes at room temperature without braking and suspended in $2 \mathrm{ml}$ of Tyrodes' buffer (10 mM Hepes, $138 \mathrm{mM} \mathrm{NaCl}, 5.5$ $\mathrm{mM}$ glucose, $12 \mathrm{mM} \mathrm{NaHCO}_{3}, 2.9 \mathrm{mM} \mathrm{KCl}$, and $0.36 \mathrm{mM} \mathrm{Na}_{2} \mathrm{HPO}_{4}, \mathrm{pH} 7.5$ ). Human venous blood was drawn from healthy volunteers who had provided informed consent, according to the Declaration of Helsinki, and had not taken any medication for seven days prior to the blood draw. Twenty-five milliliters of blood was collected into $5 \mathrm{ml}$ of ACD using a $20 \mathrm{G}$ needle and further processed using the same centrifugation procedures as described above. The platelets were suspended in $5 \mathrm{ml}$ of Tyrodes' buffer.

\section{Isolation of exosomes}

To achieve extensive platelet microvesiculation, fresh platelets were adjusted to a density of $250 \times 10^{6}$ platelets/ml with Tyrodes' buffer and incubated with $1 \mathrm{U} / \mathrm{ml}$ thrombin (Sigma-Aldrich) or PBS (control group) for $1 \mathrm{~h}$ at $37^{\circ} \mathrm{C}$. The platelets and cell debris were removed by centrifugation at 5,000 $\mathrm{g}$ for 20 minutes at room temperature. To remove large and high density microvesicles, the supernatant was transferred into new a tube (Ultra-Clear tubes, Beckman Coulter) and centrifuged at 20,000 g (SW41Ti rotor, Beckman Coulter) for 40 minutes at $4^{\circ} \mathrm{C}$. The exosome-enriched supernatants were transferred into new tubes, followed by centrifugation at $120,000 \mathrm{~g}$ for 70 minutes at $4^{\circ} \mathrm{C}$ to pellet the exosomes. The isolated exosome pellets were diluted in $200 \mu \mathrm{l}$ of PBS buffer, filtered through a $0.22 \mu \mathrm{m}$ filter, and prepared freshly at the time of use. 


\section{Cellular Physiology Cell Physiol Biochem 2016;38:2348-2365 \\ \begin{tabular}{ll|l} 
and Biochemist 10.1159/000445588 & $\begin{array}{l}\text { } 2016 \text { The Author(s). Published by S. Karger AG, Basel } \\
\text { www.karger.com/cpb }\end{array}$ \\
\hline
\end{tabular} \\ Tan et al.: Platelet-Derived Exosomes as a Biomarker for Predicting Atherothrombosis}

At four weeks after surgery, $150 \mu \mathrm{l}$ of blood was withdrawn from the jugular veins of mice into a syringe containing $50 \mu \mathrm{l}$ of $3.8 \%$ sodium citrate using a $25 \mathrm{G}$ needle. The blood was centrifuged at $300 \mathrm{~g}$ for $10 \mathrm{~min}$ at room temperature and then at 2,000 g for 30 minutes to obtain the serum. All serum samples were stored at $-80^{\circ} \mathrm{C}$ until they were pooled together to isolate the plasma exosomes. The plasma exosome isolation procedure was the same as that used to isolate the platelet-derived exosomes. Briefly, the plasma was thawed on ice, centrifuged at $1,500 \mathrm{~g}$ for 10 minutes at $4^{\circ} \mathrm{C}$, and then centrifuge at $10,000 \mathrm{~g}$ for 20 minutes to remove cell debris. The supernatant was transferred to a new tube to perform differential ultracentrifugation at 20,000 g (SW41Ti rotor, Beckman Coulter) for 40 minutes at $4^{\circ} \mathrm{C}$; then, the supernatant was transferred into a new tube and a centrifuge at $120,000 \mathrm{~g}$ for 70 minutes at $4^{\circ} \mathrm{C}$ to pellet the exosomes. The exosomes were diluted in $200 \mu \mathrm{l}$ of PBS, filtered through a $0.22 \mu \mathrm{m}$ filter, and then stored at $-80^{\circ} \mathrm{C}$ immediately after isolation.

\section{Exosome electron microscopy}

Fifty microliters of exosomes derived from human platelets were suspended in $50 \mu \mathrm{l}$ of $4 \%$ paraformaldehyde (PFA). Two microliters of this mixture was loaded onto Formvar-carbon-coated grids. The membrane was covered for 20 minutes. One hundred microliters of PBS was placed on a sheet of parafilm, to which the grids were transferred with the sample membrane side facing down using clean forceps; the grids were incubated for 2 minutes. The membrane side of the grids was kept wet during all steps. The grids were transferred to a $50 \mu \mathrm{l}$ drop of $1 \%$ glutaraldehyde for 5 minutes and then transferred to a $100 \mu \mathrm{l}$ drop of distilled water for 2 minutes. Washes were repeated 7 times. To contrast the samples, the grids were transferred to a $50 \mu \mathrm{l}$ drop of uranyl-oxalate solution for 5 minutes before being transferred to a $50 \mu \mathrm{l}$ drop of methyl-cellulose-UA for 10 minutes; the grids were then placed on a glass dish covered with parafilm on ice. The grids were removed with stainless steel loops, and the excess fluid was gently blotted. The grids were left to dry and store in appropriate grid storage boxes. Grids were observed with a transmission electron microscope at 25 to $100 \mathrm{KV}$ (JEM).

\section{Western blotting}

Exosomes were treated with lysis buffer and protease inhibitors for 30 minutes at $4^{\circ} \mathrm{C}$. Thirty micrograms of each sample was electrophoresed on a 10\% SDS-PAGE gel and transferred to a nitrocellulose membrane (Millipore). The membrane was blocked with $5 \% \mathrm{w} / \mathrm{v}$ skim milk powder in TBST $(0.1 \mathrm{M}$ Tris- $\mathrm{HCl}$ $\mathrm{pH} 8,1.5 \mathrm{M} \mathrm{NaCl}$ and $1 \%$ Tween-20) for 1 hour at room temperature, and subsequently incubated with antiGAPDH (1:2000, CST), anti-CD9 $\left(1: 1000\right.$, CST) and anti-flotillin $\left(1: 1000\right.$, CST) antibodies overnight at $4^{\circ} \mathrm{C}$. After vigorous washing in TBST, the membrane was incubated with secondary antibody (ZSBIO, China) for 1 hour at room temperature. Immuno-complexes were detected with the ECL (Thermo Scientific) western blotting analysis system.

\section{Primary vascular SMC culture}

Vascular SMCs were isolated from the aortic tissues of WT mice $(n=5)$ for primary culture [27]. In brief, the aorta was incubated with $1 \mathrm{mg} / \mathrm{ml}$ type 2 collagenase (Worthington) for 20 minutes at $37^{\circ} \mathrm{C}$. Then adventitial tissue was carefully removed and the artery was cut into $1 \mathrm{x} 1 \mathrm{~mm}$ pieces with fine scissors. The aorta pieces were cultured in DMEM (Gibco) supplemented with 10\% fetal bovine serum (Gibco) and 1\% penicillin/streptomycin (Gibco) and maintained in a humidified $5 \% \mathrm{CO}_{2}$ atmosphere at $37^{\circ} \mathrm{C}$. SMCs were identified by their "hill and valley" growth pattern and immunofluorescence with $\alpha$-SMA antibody (Abcam). We ascertain that $>95 \%$ of the cells are vascular SMCs in culture prepared from aorta arteries in which adventitia is carefully removed, and the cells should not cross-react with CD90 (fibroblast) and CD31 (endothelial) antibodies (data not shown). SMCs at passages 4-8 were used for subsequent experiments.

\section{Exosome labeling and delivery}

Exosomes were stained with PKH26 Red Fluorescent Cell Linker Kit (Sigma-Aldrich). Briefly, 30 $\mu \mathrm{g}$ of exosomes were diluted in $1 \mathrm{ml}$ of Diluent C. Four microliters of PKH26 dye was added to $1 \mathrm{ml}$ of Diluent $\mathrm{C}$ before being added to the exosomes. The samples were mixed gently for 5 minutes. Then, $2 \mathrm{ml}$ of exosome-free FBS was added to bind the excess dye. The samples were centrifuged at 120,000 g (SW41Ti rotor, Beckman Coulter) for 70 minutes at $4^{\circ} \mathrm{C}$ to obtain PKH26-labeled exosome pellets. SMCs were serumstarved for 24 hours before being co-incubated with the exosomes. approximately $0.5 \mu \mathrm{g}, 1.25 \mu \mathrm{g}$, and 2.5 


\section{Cellular Physiology Cell Physiol Biochem 2016;38:2348-2365 \\ \begin{tabular}{ll|l}
\cline { 2 - 2 } and Biochemistry $10.1159 / 000445588$ & $\begin{array}{l}\text { ( ) 2016 The Author(s). Published by S. Karger AG, Basel } \\
\text { www.karger.com/cpb }\end{array}$ \\
\hline
\end{tabular} \\ Tan et al.: Platelet-Derived Exosomes as a Biomarker for Predicting Atherothrombosis}

$\mu \mathrm{g}$ of exosomes diluted in $0.5 \mathrm{ml}$ DMEM were added to $1 \times 10^{4}$ SMCs in a 24-well plate. After 2, 5, 8, 13 and 21 hours of incubation, internalization was stopped by washing with Hank's balanced solution, and the SMCs were fixed in 4\% PFA for 20 minutes. The SMCs were then stained with $\alpha$-SMA antibody (1:1,000, Abcam) and visualized with a laser scanning confocal microscope (LSM 780, Carl Zeiss). The images were captured with a $20 \times$ objective in LineSequential scan mode at an image size of $1024 \times 1024$. The excitation wavelength was $551 \mathrm{~nm}$, and the emission wavelengths were 560-580 nm to quantify the internalized exosomes.

\section{Quantitative PCR analysis}

Total RNA from the exosomes, platelet debris, and SMCs was isolated with an miRNeasy Mini Kit (Qiagen) according to the manufacturer's instructions. SMCs plated in 24-well plates were pretreated with $2.5 \mu \mathrm{g}$ of platelet-derived exosomes supplemented with $0.5 \mathrm{ml}$ of DMEM for 24 hours, and the mRNAs and miRNAs were harvested and quantified. Because there were no endogenous internal control miRNAs in exosomes, so approximately $5.6 \times 10^{8}$ copies of cel-miR-39 (Qiagen) internal control, were added after the exosomes were lysed to quantify the miRNAs. RNA concentrations were measured on nanodrop spectrophotometer (Thermo Scientific). The RNA 260/230 ratios of the samples were 1.8 to 2.1. The primers used for qPCR were purchased from Majorbio, China, and the sequences are as follows:

\begin{tabular}{lll}
\hline Primer & & 5'-3' \\
\hline miR-223 & & TGGGGTATTTGACAAACTGACA \\
miR-339 & & CGGCTCTGTCGTCGAGGCGCTCA \\
miR-21 & & TCAACATCAGTCTGATAAGCTA \\
Gapdh & F: & TCAACAGCAACTCCCACTCTTCCA \\
& R: & ACCCTGTTGCTGTAGCCGTATTCA \\
Mapk3 & F: & TCCGCCATGAGAATGTTATAGGC \\
& R: & GGTGGTGTTGATAAGCAGATTGG \\
Mapk1 & F: & GGTTGTTCCAAATGCTGACT \\
& R: & CAACTTCAATCCTCTTGTGAGGG \\
Akt1 & F: & ATGAACGACGTAGCCATTGTG-3 \\
& R: & TTGTAGCCAATAAAGGTGCCAT \\
Rasa1 & F: & TGTGGTGATTACTACATTGGTGG \\
& R: & CGCCTTCTATCTTCTACTGGCTC \\
Mapk14 & F: & TGACCCTTATGACCAGTCCTTT \\
& R: & GTCAGGCTCTTCCACTCATCTAT \\
PDGFR $\beta$ & F: & TTCCAGGAGTGATACCAGCTT \\
& R: & AGGGGGCGTGATGACTAGG \\
Kras & F: & CAAGAGCGCCTTGACGATACA \\
& R: & CCAAGAGACAGGTTTCTCCATC \\
Prkcb & F: & AGCGAGACACCTCCAACTTC \\
& R: & CAGTGGGAGTCAGTTCCACAG \\
\hline
\end{tabular}

Quantitative PCR was performed with the Light Cycler-based SYBR Green detection system using an ABI Vii7a detector (Applied Biosystems).

miR-223 mimic transfection

miR-223 mimic and negative control miRNA were obtained from Ribobio, China. SMCs were seeded onto 24 -well plates $\left(1 \times 10^{4}\right.$ cells per well) and 12 -well plates $\left(2 \times 10^{4}\right.$ cells per well) the day before transfections were performed. Cells (70\% confluent) were transfected with miR-223 mimic (10 nM), negative control mimic $(10 \mathrm{nM})$. All transfections were carried out in triplicate with riboFECT CP reagent (Ribobio, China). Cell lysates were prepared with lysis buffer with proteinase/phosphatase inhibitor (CST) 48 hours after transfection.

Validating the effects of platelet-derived exosomes on SMCS

Serum-starved SMCs plated in 24-well plates were pretreated with $2.5 \mu \mathrm{g}$ of platelet-derived exosomes supplemented with $0.5 \mathrm{ml}$ of DMEM for 24 hours. Platelet-derived growth factor receptor-beta (PDGFR $\beta$ ) expression was determined by western blot of and staining the cells with an anti-PDGFR antibody (1:1000, CST), which was visualized by confocal microscopy (LSM 780, Carl Zeiss). The images were captured with a $20 \times$ objective in LineSequential scan mode at an image size of $1024 \times 1024$. The excitation wavelength was 


\section{Cellular Physiology Cell Physiol Biochem 2016;38:2348-2365 \begin{tabular}{l|l|l} 
and Biochemistry & $\begin{array}{l}\text { DOI: 10.1159/000445588 } \\
\text { Published online: May 23, } 2016\end{array}$ & $\begin{array}{l}\text { O 2016 The Author(s). Published by S. Karger AG, Basel } \\
\text { www.karger.com/cpb }\end{array}$ \\
\cline { 2 - 3 }
\end{tabular} \\ Tan et al.: Platelet-Derived Exosomes as a Biomarker for Predicting Atherothrombosis}

$488 \mathrm{~nm}$, and the emission wavelength was $540 \mathrm{~nm}$ to quantify the PDGFR $\beta$ expression level. SMCs were stimulated with $20 \mathrm{ng} / \mathrm{ml}$ platelet-derived growth factor-BB (PDGF-BB) (Peprotech, USA) for $24 \mathrm{~h}$ and then stained with the Ki-67 antibody (CST) and western blot of PCNA antibody (CST) for the proliferation assay. Cell apoptosis was assessed by the TUNEL assay. Briefly, SMCs were starved for 48 hours, pre-treated with exosomes for an additional 24 hours, and then incubated with PDGF-BB for 24 hours.

\section{Statistical analysis}

All statistical calculations were performed using IBM SPSS 22. All data were expressed as the means \pm S.E.M. One-way ANOVA with Tukey's post hoc test was used for multiple comparisons as appropriate. In all comparisons, a value of $p<0.05$ was considered to be statistically significant.

\section{Results}

Increased levels of miR-223, miR-339 and miR-21 in plasma exosomes before thrombosis

Fifteen of 40 mice in the tandem stenosis group developed lumen thrombus in the right common carotid artery when examined under a microscope (Fig. 1A). None of the sham mice exhibited thrombosis, erosion, or rupture, suggesting that the surgical procedure and

Fig. 1. Changes in plasma exosomal miR-223, miR-339 and miR-21 levels before thrombosis. Cross-section of HE staining of the atherothrombotic artery (A) and sham control (B). Scale bars indicate $100 \mu \mathrm{m}$. (C) Ultrasound of the mouse right common carotid artery at four weeks after surgery; no obstruction was observed. One hundred fifty microliters of blood was collected from each mouse at four weeks after surgery. The cycle threshold (CT) level of pooled plasma exosomal miR-223, miR-339 and miR-21 (D) and relative fold change (E) in sham and atherothrombosis groups. Atherothrombosis was confirmed in mice at
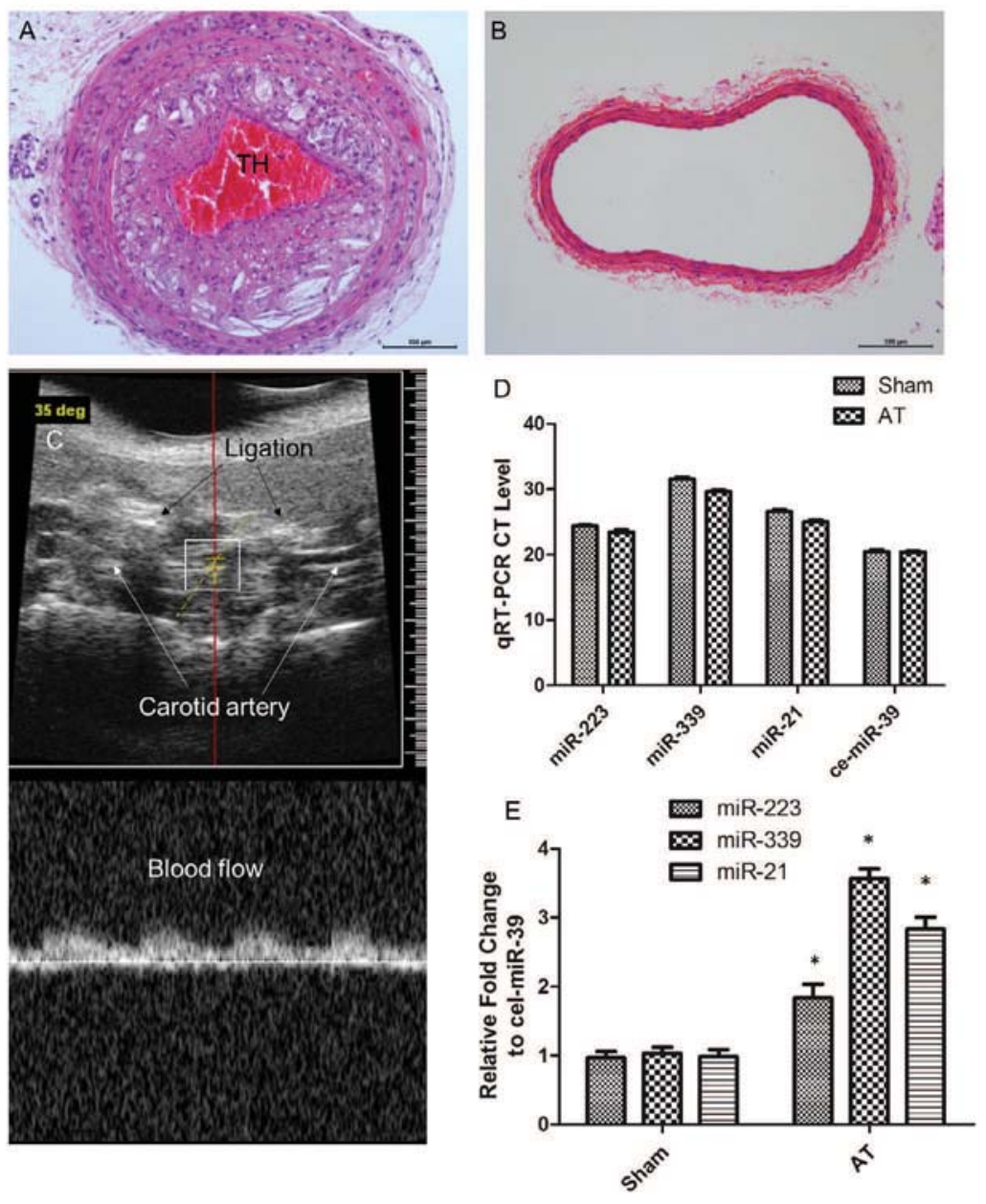

seven weeks. The mice in the sham group served as the control. Cel-miR-39 was added as an internal control. $n=4$ mice in both groups. Data are presented as the means \pm S.E.M. ${ }^{*} p<0.05$. TH: thrombus. AT: atherothrombosis. 


\section{Cellular Physiology Cell Physiol Biochem 2016;38:2348-2365 \begin{tabular}{ll|l} 
and Biochemist 10.1159/000445588 & $\begin{array}{l}\text { O } 2016 \text { The Author(s). Published by S. Karger AG, Basel } \\
\text { www.karger.com/cpb }\end{array}$ \\
\hline
\end{tabular} \\ Tan et al.: Platelet-Derived Exosomes as a Biomarker for Predicting Atherothrombosis}

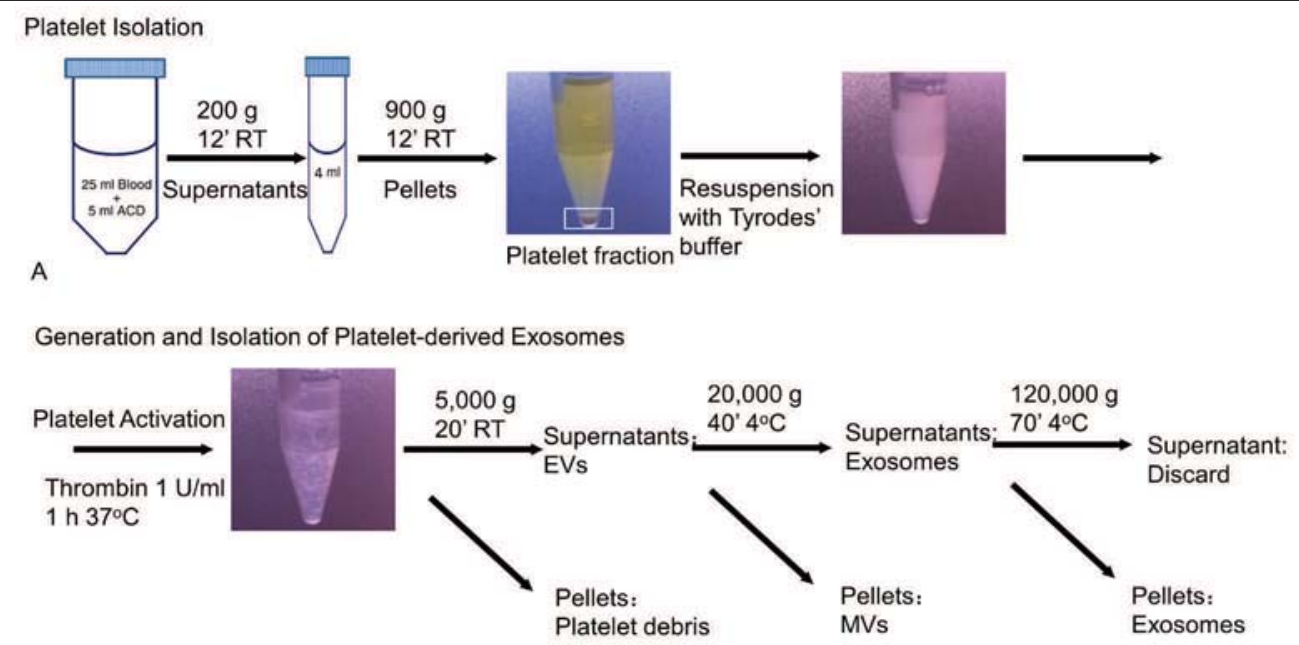

B

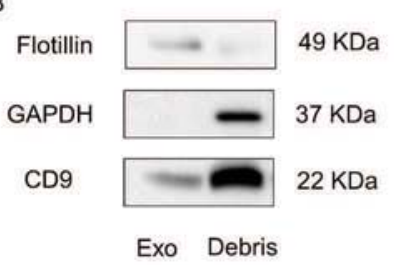

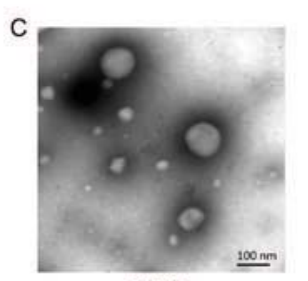

TEM

Fig. 2. Isolation and identification of thrombin-stimulated platelet-derived exosomes. (A) Flow chart for the isolation of platelet-derived exosomes. EVs: extracellular vesicles. MPs: microvesicles. (B) Western blots of CD9, flotillin and GAPDH. Thirty micrograms of exosomes and platelet debris were loaded. CD9 and flotillin are exosomal markers that were expressed in our isolated exosomes. GAPDH was expressed only in cell debris. The lack of GAPDH in the exosomes suggested that our exosomes were free of cell debris. (C) Transmission electron microscopy (TEM) image of exosomes at 100K magnificationff. Scale bar indicates $100 \mathrm{~nm}$. Exo: platelet-derived exosome.

suture itself do not induce atherothrombosis (Fig. 1B). One hundred fifty microliters of blood was collected from the jugular vein of each mouse at four weeks after tandem stenosis ligation. To confirm that a thrombus did not form at the time that blood was collected, we checked carotid artery flow with ultrasound (Fig. 1C). All mice remained alive until they were sacrificed at seven weeks. We pooled plasma from the thrombosis group $(n=4)$ and sham group $(\mathrm{n}=4)$ to isolate the exosomes. The qPCR CT levels of plasma exosomal miR-223, miR-339 and miR-21 in sham and thrombosis groups are shown in Fig. 1D. Compared with mice in the sham group, plasma exosomal miR-223 ( $1.83 \pm 0.35$ vs $0.97 \pm 0.15 ; \mathrm{p}=0.017)$, miR339 ( $3.56 \pm 0.25$ vs $1.03 \pm 0.15 ; p<0.001)$, and miR-21 ( $2.83 \pm 0.31$ vs $0.98 \pm 0.18 ; p=0.01)$ levels were significantly increased in mice in the atherothrombosis group (Fig. 1E).

\section{Activated platelet-derived exosomes contain higher levels of miR-223, miR-339 and miR-} 21

To exclude other circulating cells, such as leukocytes and monocytes, we first counted the cells using a hemocytometer. Using our methods of platelet isolation, there was no more than 1 nucleated cell in 1,000,000 platelets in our samples. To achieve extensive platelet microvesiculation, platelets were activated with $1 \mathrm{U} / \mathrm{ml}$ thrombin and incubated for 1 hour at $37^{\circ} \mathrm{C}$. The control group was also incubated for 1 hour at $37^{\circ} \mathrm{C}$ but in the absence of thrombin. We isolated and purified human and mouse platelet-derived exosomes through several steps of ultracentrifugation (Fig. 2A). Exosomes were identified by western blotting and transmission electron microscopy. The exosomal marker CD9, a member of the 


\section{Cellular Physiology Cell Physiol Biochem 2016;38:2348-2365 \begin{tabular}{c|c|c|c|c|}
\hline DOI: 10.1159/000445588 & () 2016 The Author(s). Published by S. Karger AG, Basel
\end{tabular}

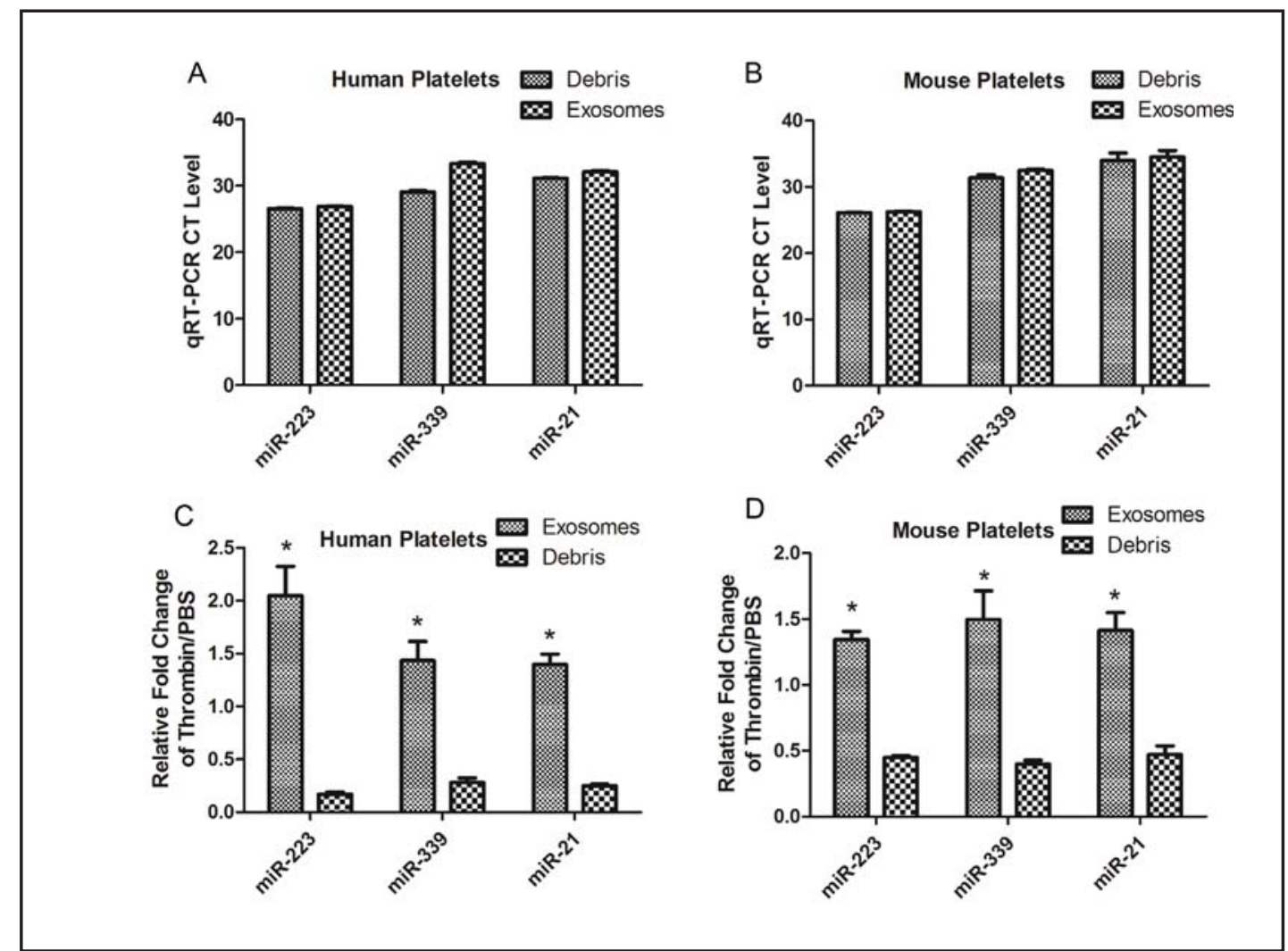

Fig. 3. miR-223, miR-339 and miR-21 expression in thrombin-treated platelet-derived exosomes and debris. The cycle threshold (CT) level of miR-223, miR-339 and miR-21 in thrombin (1 U/ml) treated platelet-derived exosomes and debris of human platelets (A) and mouse platelets (B). Relative fold change in miR-223, miR-339 and miR-21 levels in human platelet-derived exosomes or debris that were pre-treated with thrombin (C) and mouse platelet-derived exosomes or debris that were pre-treated with thrombin (D)

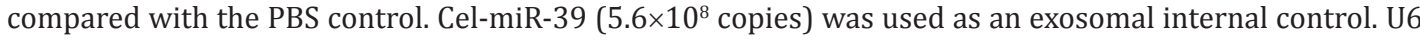
was used as a debris internal control. CT levels of the miRNAs were analyzed in triplicate. $n=3$ independent experiments. Data are presented as the means \pm S.E.M. ${ }^{*} \mathrm{p}<0.05$.

tetraspanin family, was expressed in both exosomes and platelet debris, whereas flotillin, a lipid raft protein, was expressed only in exosomes. The expression of CD9 in the cell debris suggested that there were still endosomal compartments in the platelet debris. CD9 and flotillin expression ensured that we had isolated the exosomes, as previously reported [28] (Fig. 2B). As a housekeeping gene that is commonly expressed in cells, GAPDH was absent from the exosomes, which suggested that the exosomes isolated in this study were free of cell debris. The transmission electron microscopy results clearly showed that exosomes with a characteristic rounded morphology and a typical size range of 30-150 nm were present (Fig. 2C).

We isolated miRNAs from platelet-derived exosomes and debris. Humans and mice share the same miR-223, miR-339 and miR-21 sequences (www.miRBase.org). The qPCR CT levels of miR-223, miR-339 and miR-21 in thrombin-treated platelets are shown in Fig. 3A and $3 \mathrm{~B}$. Both human and mouse miR-223 was the most predominantly expressed miRNA in platelet-derived exosomes and cell debris. Compared with PBS-treated platelets and platelet debris, thrombin-treated human platelets were enriched with miR-233 in the exosomes $(2.05 \pm 0.48$ vs $0.17 \pm 0.04 ; p=0.002 ; n=3)$. Similar results were observed for miR-339 $(1.43 \pm 0.31$ vs $0.28 \pm 0.07 ; \mathrm{p}=0.003 ; \mathrm{n}=3)$ and miR-21 $(1.40 \pm 0.17$ vs $0.25 \pm 0.02 ; \mathrm{p}<0.001 ; \mathrm{n}=3)$ in thrombin-treated platelet-derived exosomes compared with debris (Fig. 3C). In thrombin-treated mouse platelets, miR-223 ( $1.34 \pm 0.10$ vs $0.45 \pm 0.02 ; \mathrm{p}<0.001 ; \mathrm{n}=3)$, miR-339 $(1.50 \pm 0.38$ vs $0.40 \pm 0.05 ; \mathrm{p}=0.007 ; \mathrm{n}=3)$ and miR-21 (1.41 \pm 0.23 vs $0.47 \pm 0.12 ; \mathrm{p}=0.003 ; \mathrm{n}=3)$ levels were KARGER 


\section{Cellular Physiology Cell Physiol Biochem 2016;38:2348-2365 \begin{tabular}{l|l|l|l} 
and Biochemistry 10.1159/000445588 & 2016 The Author(s). Published by S. Karger AG, Basel \\
\hline
\end{tabular} and Biochemistry Published online: May 23, 2016 www.karger.com/cpb}

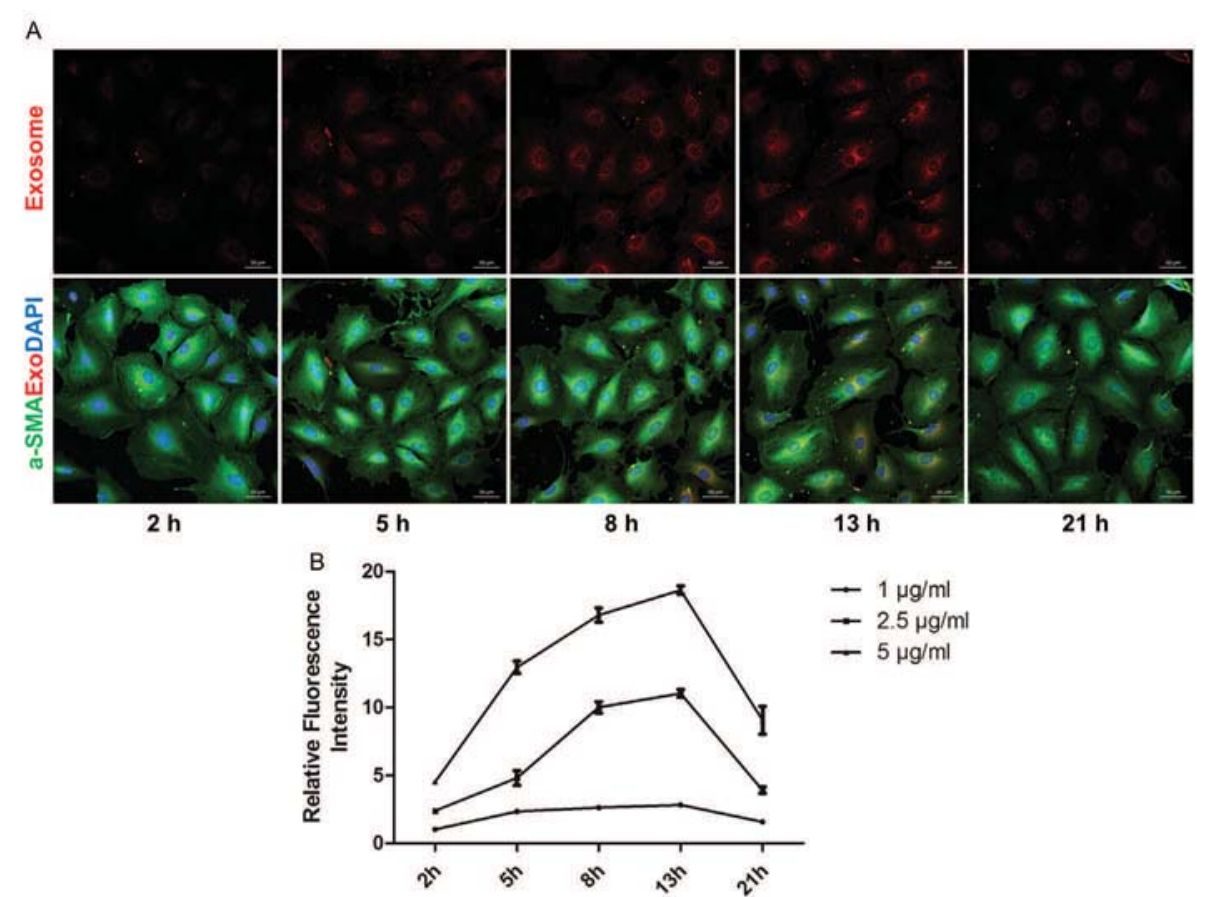

Fig. 4. SMCs take up platelet-derived exosomes in a concentration-and-time dependent manner. (A) Approximately $5 \mu \mathrm{g} / \mathrm{ml}$ PKH26 labeled exosomes (red) was added to the SMCs and incubated for 2, 5, 8, 13 and 21 hour. The uptake of exosomes by SMCs is shown as red fluorescence around the nucleus. Cellular uptake of fluorescently labeled exosomes was detected by confocal microscopy. Images were captured with $20 \times$ objective in LineSequential scan mode at an image size of $1024 \times 1024$. The excitation wavelength was $551 \mathrm{~nm}$, and the emission wavelengths were 560-580 nm to obtain the amount of internalized exosomes. SMCs were stained with an anti- $\alpha$-SMA antibody. Scale bars indicate $100 \mu \mathrm{m}$. (B) Relative fluorescence intensity of internalized exosomes in SMCs that were treated with $1 \mu \mathrm{g} / \mathrm{ml}, 2.5 \mu \mathrm{g} / \mathrm{ml}$ and $5 \mu \mathrm{g} / \mathrm{ml}$ solutions of labeled exosomes. Red fluorescence of the internalized exosomes $(1 \mu \mathrm{g} / \mathrm{ml})$ within 2 hours was used as the baseline. SMC uptake of the exosomes $(5 \mu \mathrm{g} / \mathrm{ml})$ followed a time-dependent parabolic curve: $f(x)=-0.1345 x^{2}+3.2978 x-1.0153, x(h), R^{2}=0.9906 . n=3$ independent experiments. Data are presented as the means \pm S.E.M. of 10 fields per slide. ${ }^{*} p<0.05$.

also enriched in the exosomes compared with platelet debris (Fig. 3D).

Uptake of platelet-derived exosomes by SMCS in a concentration-and-time-dependent manner

Different concentration of PKH26-labeled exosomes (red) were incubated with SMCs for various times. Uptake of exosomes by SMCs was shown as red fluorescence around the nucleus (Fig. 4A). To quantify the
Table 1. Relative red fluorescence intensity. PKH26-labeled exosomes were incubated with SMCs at concentrations of $1 \mu \mathrm{g} / \mathrm{ml}, 2.5 \mu \mathrm{g} / \mathrm{ml}$ and $5 \mu \mathrm{g} / \mathrm{ml}$ for $2,5,8,13$ and 21 hour. Images were captured with a $20 \times$ objective in LineSequential scan mode at an image size of $1024 \times 1024$. The excitation wavelength was $551 \mathrm{~nm}$ and the emission wavelengths were $560-580 \mathrm{~nm}$ to obtain the amount of internalized exosomes. Red fluorescence of $1 \mu \mathrm{g} /$ $\mathrm{ml}$ exosomes at 2 hours was used as the baseline. $\mathrm{n}=3$ independent experiments. Data are presented as the means \pm S.E.M. of 1010 fields per slide

\begin{tabular}{lcllc}
\hline Fluorescence & \multicolumn{4}{c}{ Exosome concentration } \\
Intensity & $1 \mu \mathrm{g} / \mathrm{ml}$ & $2.5 \mu \mathrm{g} / \mathrm{ml}$ & $5 \mu \mathrm{g} / \mathrm{ml}$ & $\mathrm{p}$ \\
\hline $2 \mathrm{~h}$ & $1.02 \pm 0.12$ & $2.39 \pm 0.08$ & $4.51 \pm 0.15$ & $<0.001$ \\
$5 \mathrm{~h}$ & $2.34 \pm 0.11$ & $4.81 \pm 0.54$ & $12.95 \pm 0.46$ & $<0.001$ \\
$8 \mathrm{~h}$ & $2.63 \pm 0.09$ & $10.00 \pm 0.43$ & $16.79 \pm 0.52$ & $<0.001$ \\
$13 \mathrm{~h}$ & $2.82 \pm 0.16$ & $11.03 \pm 0.29$ & $18.63 \pm 0.31$ & $<0.001$ \\
$21 \mathrm{~h}$ & $1.58 \pm 0.09$ & $3.91 \pm 0.24$ & $9.05 \pm 1.03$ & $<0.001$ \\
\hline
\end{tabular}




\section{Cellular Physiology Cell Physiol Biochem 2016;38:2348-2365 \begin{tabular}{c|c|c|} 
DOI: 10.1159/000445588 & ( 2016 The Author(s). Published by S. Karger AG, Basel \\
and Biochemistry Published
\end{tabular} \\ Tan et al.: Platelet-Derived Exosomes as a Biomarker for Predicting Atherothrombosis}

Fig. 5. Validated expression of platelet-derived exosome target genes in cocultured SMCs. (A) The miR-223, miR-339 and miR-21 levels in SMCs that had been treated with platelet-derived exosomes (5 $\mu \mathrm{g} / \mathrm{ml}$ ) were compared with those in PBS controls after 24 hours of incubation. (B) Genes in the MAPK signaling pathway that were targeted by miR223/339/21. The red box represents a target site for miRNA in the indicated gene. (C) CT level of the target genes' mRNAs in the SMCs that had been incubated with exosomes compared with the PBS control at 24 hours. (D) Relative fold change in the target genes' mRNA levels in the SMCs that had been incubated with exosomes compared with the PBS control at 24 hours. SMCs were starved for 24 hours before they were incubated with the exosomes. CT levels of the mRNAs were analyzed in triplicate. (E) The predicted miRNA/
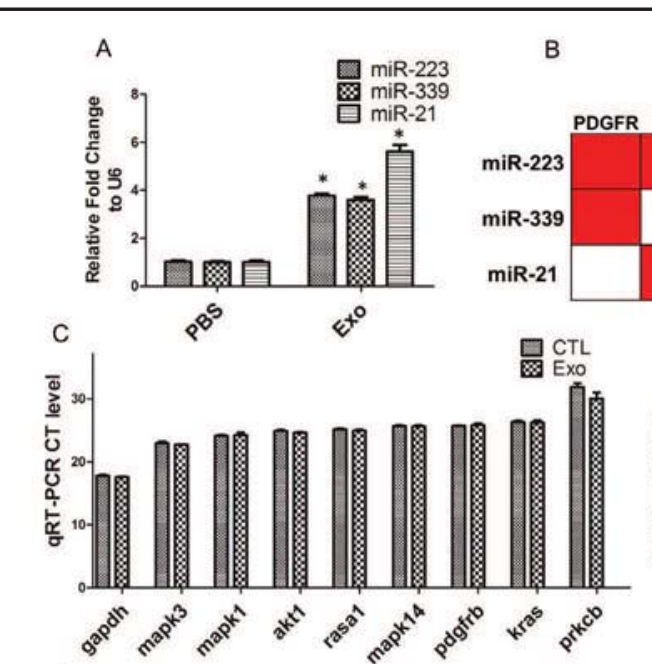

B Proliferation genes

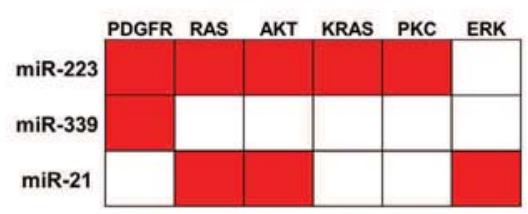

D

$\mathrm{E}$
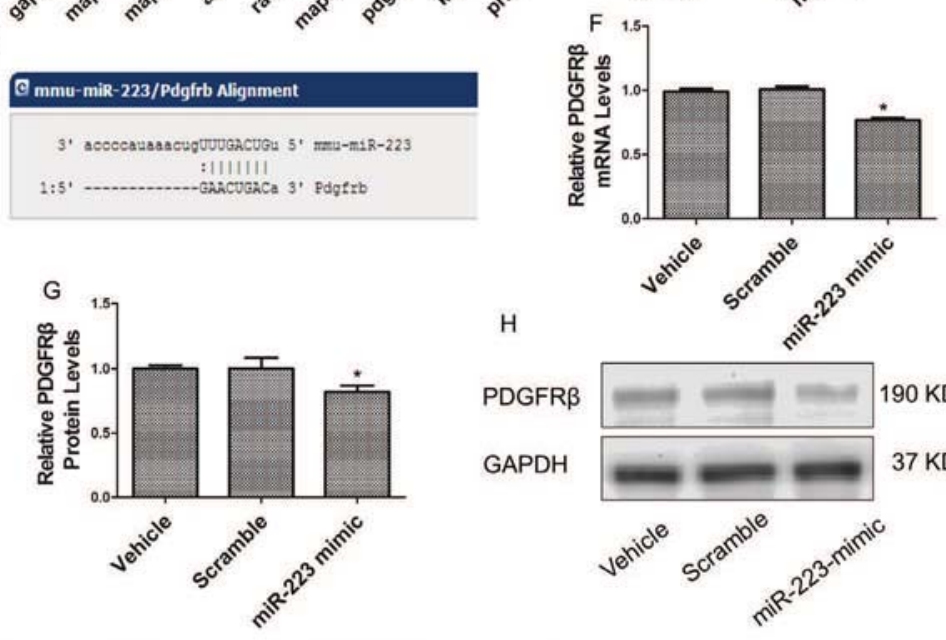

H

PDGFR $\beta$

GAPDH
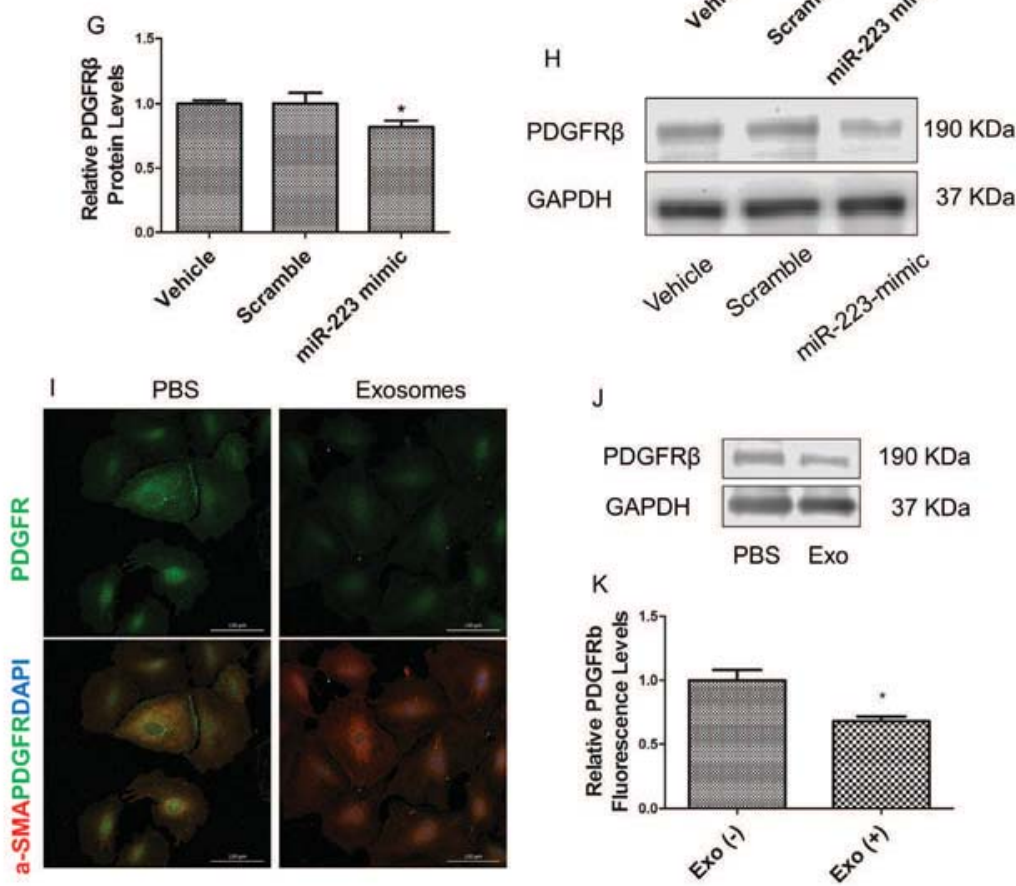

品
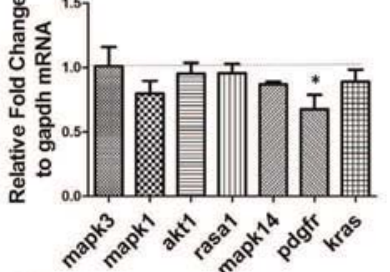

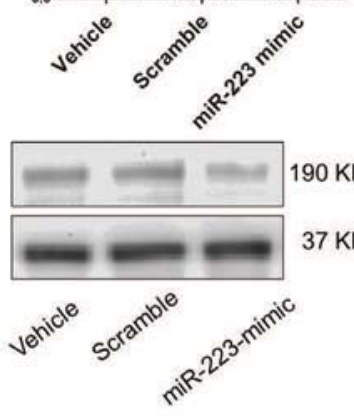

J

$2 e^{\alpha^{2}} c^{\alpha}$

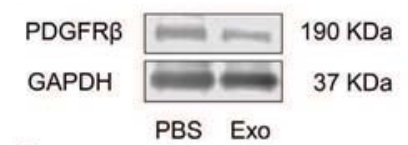

K

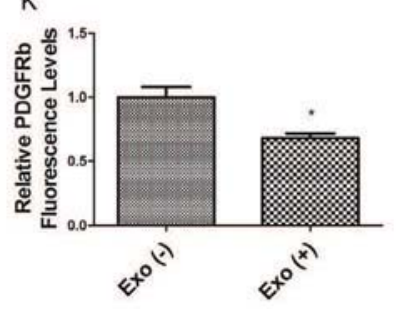

PDGFR $\beta$ sequence alignments. The data were from microRNA.org. (F) Overexpression of miR-223 decreased the expression of PDGFR $\beta$ at mRNA level. Relative fold change of PDGFR $\beta$ mRNA level in the SMCs that had been transfected with miR-223 mimic $(10 \mathrm{nM})$ compared with the vehicle and scramble control at 48 hours. $(G, H)$ Western blot of PDGFR $\beta$ in SMCs that were treated with a miR-223 mimic, decreased protein level at 48 hours of treatment. $n=3$ independent experiments. Data are presented as the means \pm S.E.M. ${ }^{*} p<0.05$. (I to K) Platelet-derived exosomes inhibit PDGFR $\beta$ expression in SMCs. PDGFR $\beta$ expression in SMCs was determined by measuring fluorescence intensity under a confocal microscope and western blotting. Images were captured with a $20 \times$ objective in LineSequential scan mode at an image size of $1024 \times 1024$. The excitation wavelength was $488 \mathrm{~nm}$ and emission wavelength was $540 \mathrm{~nm}$ to obtain PDGFR $\beta$ expression levels. $\mathrm{n}=6$ independent experiments. Data are presented as the means \pm S.E.M. from 10 fields per slide. ${ }^{*} \mathrm{p}<0.05$. 


\section{Cellular Physiology Cell Physiol Biochem 2016;38:2348-2365 \\ \begin{tabular}{ll|l} 
and Biochemistry & $\begin{array}{l}\text { DOI: 10.1159/000445588 } \\
\text { Published online: May 23, } 2016\end{array}$ & $\begin{array}{l}\text { ( ) } 2016 \text { The Author(s). Published by S. Karger AG, Basel } \\
\text { www.karger.com/cpb }\end{array}$ \\
\cline { 1 - 3 }
\end{tabular} \\ Tan et al.: Platelet-Derived Exosomes as a Biomarker for Predicting Atherothrombosis}

Table 2. Pathways that were enriched in miR-223/339/21 targeted genes. The database used for this analysis was DAVID-Tools

\begin{tabular}{llll}
\hline KEGG pathway in human & PValue & KEGG pathway in mouse & PValue \\
\hline Cell cycle & $6.56 \mathrm{E}-10$ & Jak-STAT signaling pathway & $4.02 \mathrm{E}-05$ \\
Focal adhesion & $3.82 \mathrm{E}-06$ & MAPK signaling pathway & $1.84 \mathrm{E}-04$ \\
p53 signaling pathway & $2.15 \mathrm{E}-05$ & Cell cycle & 0.00337 \\
MAPK signaling pathway & $9.04 \mathrm{E}-04$ & Focal adhesion & 0.00370 \\
TGF-beta signaling pathway & 0.01562 & Apoptosis & 0.03805 \\
Apoptosis & 0.01562 & p53 signaling pathway & 0.07573 \\
\hline
\end{tabular}

fluorescence level, we used the same excitation and emission wavelengths and obtained red fluorescence by confocal microscopy. We defined red fluorescence of $1 \mu \mathrm{g} / \mathrm{ml}$ exosomes at 2 hours as the baseline. Quantitation of the fluorescence levels of different concentrations of exosomes at different times is shown in Table 1 and Fig. 4B. Exosome $(5 \mu \mathrm{g} / \mathrm{ml})$ uptake by SMCs followed a time-dependent parabolic curve: $\left[\mathrm{f}(\mathrm{x})=-0.1345 \mathrm{x}^{2}+3.2978 \mathrm{x}-1.0153, \mathrm{x}(\mathrm{h})\right.$, $\left.\mathrm{R}^{2}=0.9906\right]$. This formula indicated that uptake of platelet-derived exosomes by SMCs started at 0.5 hours of incubation, reached a peak at 12.25 hours, and then vanished at 24.20 hours. These results suggested that SMCs took up exosomes in a concentration-and-time-dependent manner.

Validation of the expression of target genes of platelet-derived exosomes in SMCs

The miRNAs that were enriched in plasma and platelet-derived exosomes (Fig. 1 and 3) were quantified in SMCs after treatment with platelet-derived exosomes, and, as expected, miR-223, miR-339 and miR-21 were also abundantly expressed in SMCs that were treated with platelet-derived exosomes compared with PBS-treated controls (Fig. 5A). We hypothesized that miR-223, miR-339 or miR-21 would have a function in SMCs and analyzed the pathways that were enriched in the miR-223/339/21 target genes. All experimentally supported targets of these miRNAs in DIANA Tools were listed[29] and uploaded to the DAVID Tools program (https://david.ncifcrf.gov/)[30] to perform gene enrichment KEGG pathway analysis. We obtained a list of recommended pathways (Table 2), with the miRNA target genes shown in the red box (Fig. 5B). The mRNA expression levels of the target genes were compared in SMCs that had been incubated with platelet-derived exosomes and PBS controls (Fig. 5C), and the platelet-derived growth factor receptor-beta (PDGFR $\beta$ ) mRNA level was significantly decreased following incubation with platelet-derived exosomes incubation (0.67 \pm 0.19 vs $1.00 \pm 0.05 ; \mathrm{p}=0.048$; $\mathrm{n}=3$ ) (Fig. $5 \mathrm{D})$.

Because PDGFR $\beta$ is also one of the predicted targets of miR-223 in mice (Fig. 5E), to test this, the miR-223 mimic ( $10 \mathrm{nM})$ was transfected into SMCs, and the PDGFR $\beta$ expression was determined at both the mRNA and protein levels. The expression of PDGFR $\beta$ was down-regulated in SMCs at mRNA levels (vehicle vs scramble vs miR-223 mimic: $0.99 \pm 0.02$ vs $1.00 \pm 0.02$ vs $0.76 \pm 0.02 ; p<0.001 ; n=3)$ and at protein level $(1.00 \pm 0.11$ vs $1.00 \pm 0.10$ vs $0.75 \pm 0.06$; $p=0.033$; $n=3$ ) (Fig. $5 \mathrm{~F}$ to $5 \mathrm{H}$ ). As expected, the PDGFR $\beta$ protein was significantly decreased in the platelet-derived exosome-treated SMCs compared with the PBS-treated group ( $0.68 \pm 0.09$ vs $1.00 \pm 0.20 ; \mathrm{p}=0.005 ; \mathrm{n}=6)$ (Fig. 5 I to $5 \mathrm{~K})$. The consistency of the changes in PDGFR $\beta$ mRNA and protein levels in the SMCs suggested that PDGFR $\beta$ is a target of platelet-derived exosomes.

Effects of platelet-derived exosomes on SMCS

Growth-arrested SMCs were pre-treated with platelet-derived exosomes $(5 \mu \mathrm{g} / \mathrm{ml})$ for 24 hours and then incubated with PDGF-BB $(20 \mathrm{ng} / \mathrm{ml})$. The cell proliferation rate was measured by anti-Ki67 immunostaining and visualized under a confocal microscope, western blot of PCNA was also performed to analyze the proliferating cells. PDGF-BB significantly promoted proliferation compared with the PBS control group $(8.40 \pm 2.83 \%$ vs $3.80 \pm 0.94 \%$; $\mathrm{p}=0.022 ; \mathrm{n}=4)$. However, PDGF-stimulated proliferation was efficiently inhibited in SMCs 


\section{Cellular Physiology Cell Physiol Biochem 2016;38:2348-2365 \begin{tabular}{cc|l}
\hline DOI: 10.1159/000445588 & ( ) 2016 The Author(s). Published by S. Karger AG, Basel \\
www
\end{tabular}}

Tan et al.: Platelet-Derived Exosomes as a Biomarker for Predicting Atherothrombosis

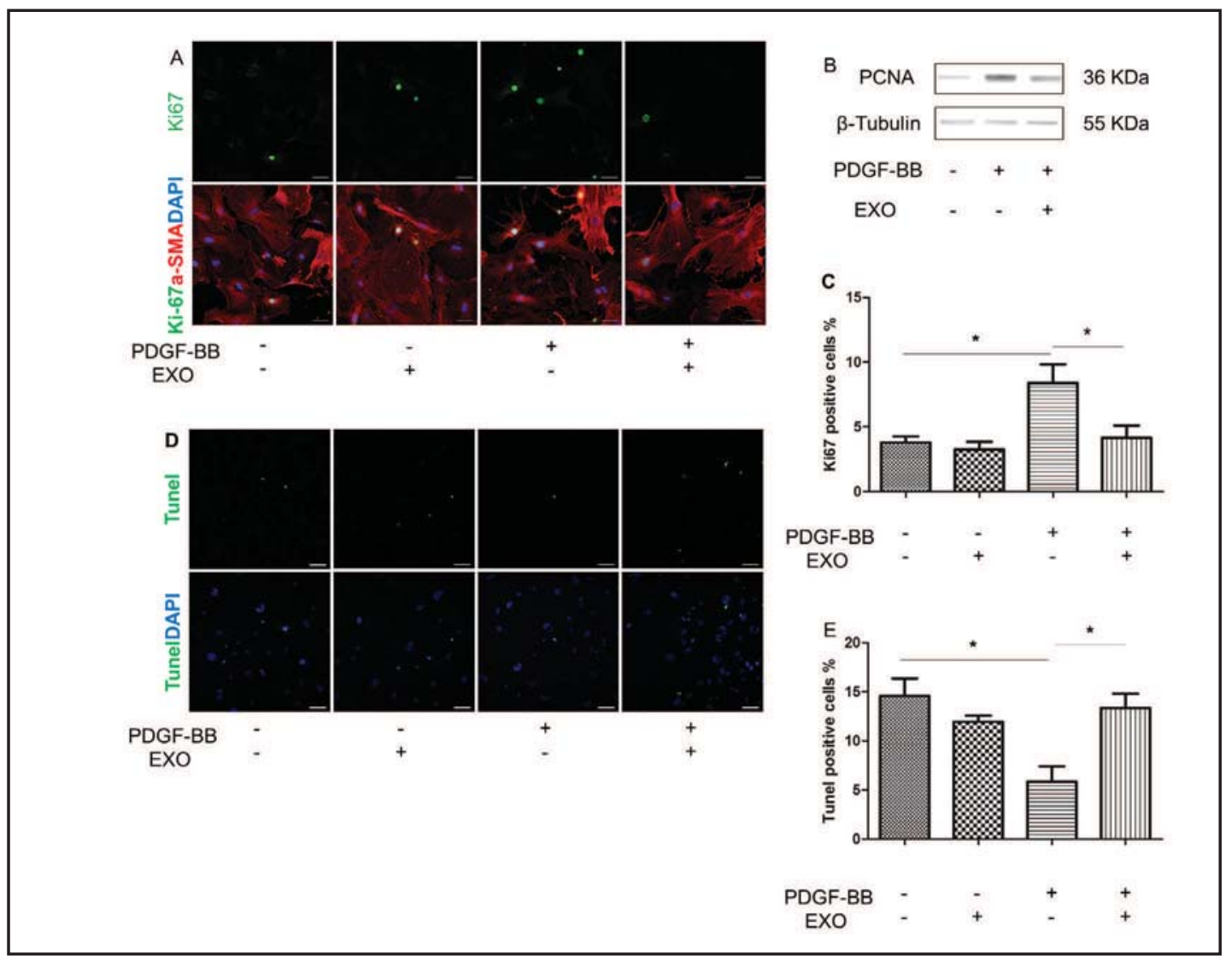

Fig. 6. Platelet-derived exosomes inhibit PDGF-stimulated SMC proliferation. SMCs plated in 24-well plates were starved for 24 hours and then incubated with $5 \mu \mathrm{g} / \mathrm{ml}$ platelet-derived exosomes for 24 hours prior to the addition of PDGF-BB (20 ng/ml). (A) Immuno-fluorescence staining of Ki-67-positive cells was measured by confocal microscopy. Images were captured with a $20 \times$ objective in LineSequential scan mode at an image size of $1024 \times 1024$. The excitation wavelength was $488 \mathrm{~nm}$, and the emission wavelength was $540 \mathrm{~nm}$ to obtain Ki-67 expression. Scale bars indicate $100 \mu \mathrm{m}$. (B) Western blots of PCNA and $\beta$-tubulin in SMCs that treated with PDGF-BB and exosomes. (C) Statistical analysis of the cell proliferation rate. The proliferation rate was defined as the number of Ki-67-positive cells/total cells in a slide. $n=4$ independent experiments, 10 fields per slide. Data are presented as the means $\pm S E M,{ }^{*} p<0.05$. (D) Apoptosis rates were measured by calculating the percentage of TUNEL-positive cells using confocal microscopy. Images were captured with a $20 \times$ objective. Scale bars indicate $100 \mu \mathrm{m}$. SMCs were starved for 48 hours and then pre-treated with exosomes for an additional 24 hours. The TUNEL assay was performed after the cells had been treated with PDGF-BB for 24 hours. (E) Statistical analysis of the cell apoptosis rate. The apoptosis rate was defined as the number of TUNEL-positive cells/total cells in a slide. $n=3$ independent experiments, 10 fields per slide. Data are presented as the means \pm S.E.M, ${ }^{*} \mathrm{p}<0.05$.

that were pre-treated with exosomes $(4.15 \pm 1.91 \%$ vs $8.40 \pm 2.83 \%$; $=0.047 ; n=4)$ (Fig. $6 \mathrm{~A}$ to $6 \mathrm{C}$ ). Next, we investigated the effects of platelet-derived exosomes on inhibiting the antiapoptotic effects of PDGF-BB. SMCs were starved for 48 hours, pre-treated with exosomes for an additional 24 hours, and then incubated with PDGF-BB for 24 hours. Cells apoptosis rates were measured with the TUNEL assay and visualized by confocal microscopy (Fig. 6D). PDGF-BB significantly promoted cell viability during long term starvation by inhibiting apoptosis ( $5.85 \pm 1.57 \%$ vs $14.58 \pm 1.78 \%$; $\mathrm{p}=0.021 ; \mathrm{n}=3$ ), but the platelet-derived exosomes abolished the anti-apoptotic effects of PDGF-BB $(13.35 \pm 1.45 \%$ vs $5.85 \pm 1.57 \%$; $\mathrm{p}=0.025$; $n=3$ ) (Fig. 6E). 


\section{Cellular Physiology Cell Physiol Biochem 2016;38:2348-2365 \begin{tabular}{c|c|c|c|c|}
\hline DOI: 10.1159/000445588 & () 2016 The Author(s). Published by S. Karger AG, Basel
\end{tabular} and Biochemistry Published online: May 23, 2016 www.karger.com/cpb}

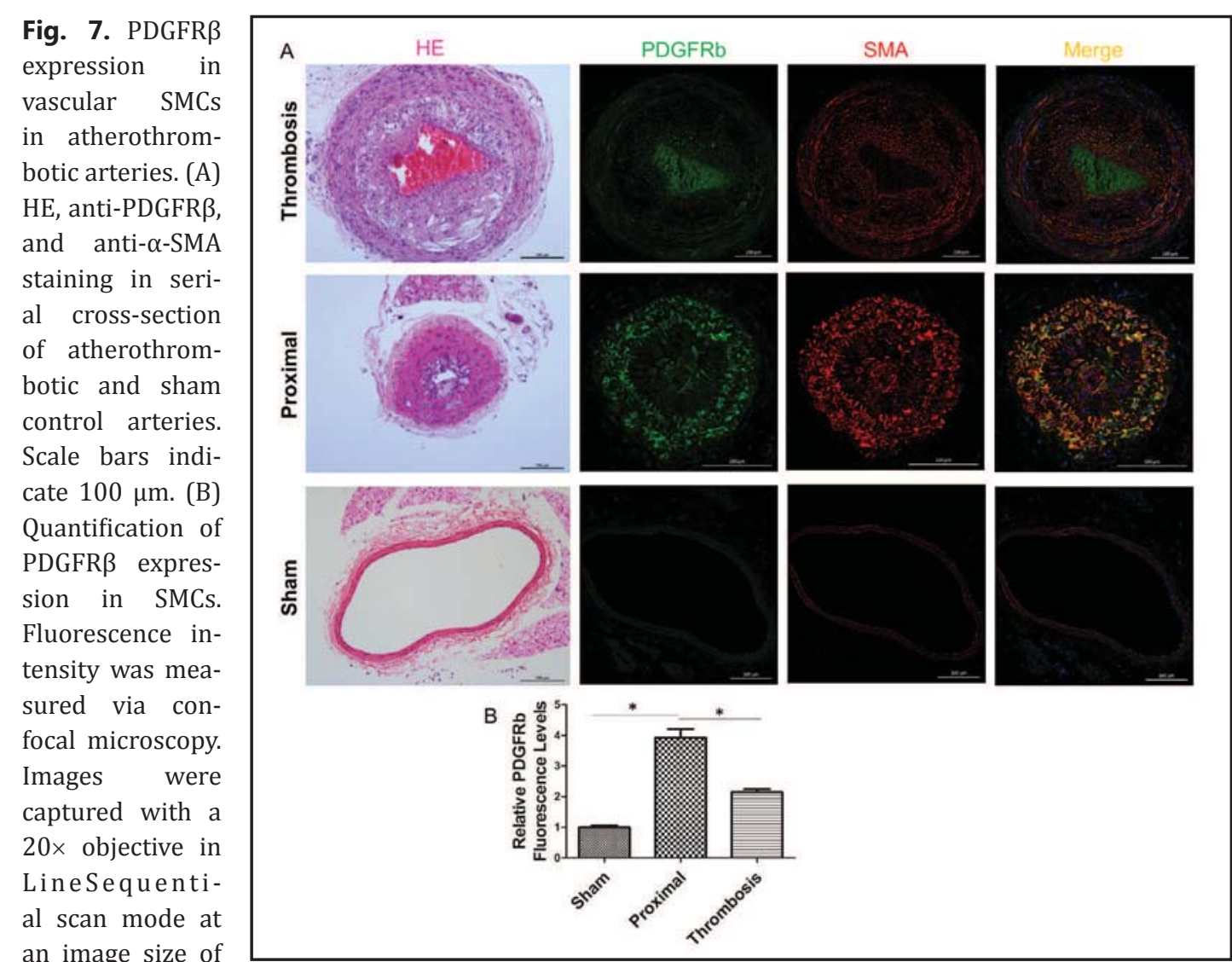

image size of

$1024 \times 1024$. The excitation wavelength was $488 \mathrm{~nm}$ and the emission wavelength was $540 \mathrm{~nm}$ to obtain PDGFR $\beta$ expression levels. $n=6$ mice per group. Data are presented as the means \pm S.E.M. ${ }^{*} \mathrm{p}<0.05$.

Decreased expression of PDGFRß in SMCs was associated with thrombosis in vivo

The cross-section of the right carotid artery showed that tandem stenosis surgery caused a significant decrease in the size of the vascular lume, particularly in the section proximal to the thrombosis (Fig. 7A). Atherosclerosis was associated with increased PDGFR $\beta$ expression compared with the sham group ( $3.03 \pm 0.42$ vs $1.00 \pm 0.10 ; \mathrm{p}<0.001 ; \mathrm{n}=6)$. However, PDGFR $\beta$ levels in the thrombotic section in SMCs were decreased compared with those in the proximal section $(2.15 \pm 0.10$ vs $3.92 \pm 0.28 ; \mathrm{p}=0.004 ; \mathrm{n}=6)$ (Fig. $7 \mathrm{~A}$ and $7 \mathrm{~B}$ ). This phenomenon was consistent with our in vitro experiments, but due to the limited amount of platelets in mouse blood, elucidating the function of platelet-derived exosomes in vivo requires further study.

\section{Discussion}

Many studies have been performed to characterize plaque vulnerability and predict future ACS events and have used techniques such as coronary computed tomography angiography (CCTA) and intravascular imaging. Based on CCTA, Motoyama found that $16 \%$ of patients with high-risk plaques (HRPs) and 1.4\% without HRPs developed ACS within a mean time of 3.9-years [31]. However, in the PROSPECT study, less than $10 \%$ of patients with thin capped plaques experienced coronary events during a 3.4-year follow-up period; the vast majority of vulnerable plaques rarely provoke ACS [3]. Therefore, transitioning from a focus on individual lesions to a risk factor assessment may be a promising approach to predict cardiovascular events [4].The consequences of atherothrombosis depend not only on the atheroma itself, but also on the fluid phase of blood flow [32]. Rittersma studied 


\section{Cellular Physiology Cell Physiol Biochem 2016;38:2348-2365 \\ \begin{tabular}{ll|l} 
DOI: 10.1159/000445588 & $\begin{array}{l}\text { () } 2016 \text { The Author(s). Published by S. Karger AG, Base } \\
\text { www.karger.com/cpb }\end{array}$ \\
\hline
\end{tabular}}

thrombus aspiration from primary PCI in acute STEMI patients and found that thrombus may form days or weeks before the on-set of symptoms in at least $50 \%$ of patients [33], suggesting that platelet activation may send a message before thrombotic events occur.

Circulating miRNAs with a variety of functions were primarily packaged in extracellular vesicles, suggesting that miRNAs may be a biomarker of cardiovascular diseases. In the present study, we observed that plasma exosomal miR-223, miR-339 and miR-21 levels were elevated before thrombosis in a carotid tandem stenosis mouse model. Meanwhile, miR-223, miR-339 and miR-21 levels were increased in thrombin-activated platelet-derived exosomes. Remarkably, platelet-derived exosomes could transfer miR-223, miR-339 and miR-21 to vascular SMCs and reduce PDGFR $\beta$ expression in vitro, resulting in inhibition of SMC proliferation and promotion of SMC apoptosis. Furthermore, PDGFR $\beta$ expression was also decreased in thrombotic lesions compared with atherosclerotic areas. Our results may provide a new perspective that activated platelet-derived exosomes regulate gene expression in vascular SMCs. Platelet-derived exosomal miRNAs may be a novel biomarker for thrombotic events.

Coronary thrombosis is the major cause of mortality and morbidity in atherosclerosis. An appropriate animal model is urgently needed to provide a better understanding of this disease [1]. In the present study, we performed carotid artery tandem stenosis in an ApoE 1- mouse fed a western diet. High cholesterol, vascular wall stress and disturbed blood flow caused severe atherosclerosis and thrombosis. Vascular SMCs residing in normal arteries exhibit a contractile phenotype and low proliferative rate [34]; however, atherosclerosis and vessel injury will cause vascular SMC migration and proliferation[35]. The current perspective is that most vulnerable plaques tend to rupture and heal, but under "perfect storm" conditions of hyper-coagulation or hypo-fibrinolysis, exposed collagen will trigger the coagulation cascade and cause thrombosis [4]. In our atherothrombosis mouse model, tandem stenosis surgery successfully created thrombosis with atherosclerosis. We speculated that activated platelet-derived exosomes participated in intercellular communication with vascular SMCs and prepare the conditions for activating the coagulation cascade.

Platelets are often activated by increased shear stress, particularly around atherosclerotic regions [36, 37]. Activation of platelets and subsequent thrombin generation may amplify the release of exosomes from platelets to local atherosclerotic areas. Two large studies combined thrombin receptor PAR-1 (protease activated receptor-1) or a factor Xa antagonist with aspirin and clopidogrel and showed a benefit of reduced risk of cardiovascular death, myocardial infarction, or stroke in selected patients with previous myocardial infarction[38, 39]. Platelet activation and thrombin generation are mutual reactions in ACS. An understanding of the activated uptake of platelet-released exosomes into vascular cells may provide a way to understand recurrent ischemic events.

Thrombin is the main effector protease of the coagulation cascade, and it is short lived in the circulation. Thus thrombin is thought to act near the site at which it is produced $[40,41]$. We used a high thrombin concentration $\left(1 \mathrm{U} / \mathrm{ml}\right.$ for 1 hour at $\left.37^{\circ} \mathrm{C}\right)$ in vitro to reflect the local site of thrombin generation and to obtain extensive platelet activation and microvesiculation[20]; the control group was incubated with PBS for 1 hour at $37^{\circ} \mathrm{C}$. The expression levels of the exosomal marker CD9, one of the most frequently identified proteins of the tetraspanin family, and flotillin, a lipid raft protein and exosomal marker. GAPDH is often used as an internal control for cellular protein. Using our method for isolation plateletderived exosomes, we showed that the exosomes expressed both CD9 and flotillin, but not GAPDH. This result indicated that our isolated exosomes were free of cellular debris. The platelet debris expressed GAPDH and CD9, but not flotillin. We speculated that there were still endosomal bodies that were not released as exosomes in platelet debris.

miR-223 is one of the most highly expressed miRNAs in plasma, and it is reported to be associated with platelet activation [17]. miR-339 and miR-21 were also associated with platelet activation[16]. To our knowledge, there are only three studies about the relationship between circulating miRNAs and future cardiovascular events [42-44]. In this work, we used atherothrombosis mouse models to estimate the association between thrombosis and 


\section{Cellular Physiology Cell Physiol Biochem 2016;38:2348-2365 \\ \begin{tabular}{ll|l} 
DOI: 10.1159/000445588 & $\begin{array}{l}\text { () } 2016 \text { The Author(s). Published by S. Karger AG, Base } \\
\text { www.karger.com/cpb }\end{array}$ \\
\hline
\end{tabular}}

plasma exosomal miR-223, miR-339 and miR-21 levels, which were associated with platelet activation. Although miR-339 had the largest fold increase, it had the highest CT level. Leukocytes and monocytes also abundantly express with miRNAs. To exclude contamination from other circulating cells, we aspirated only the top $60 \%$ of the platelet-rich plasma, and the hemocytometer showed that our platelet buffer solution contained less than 1 leukocyte per 1,000,000 platelets. This was thought to be acceptable for platelet-derived miRNAs [13]. Our results revealed that miR-223 was the most abundant miRNA in exosomes, and was expressed at the same level as in platelet debris. Plasma miR-223 could enter SMCs in the vascular wall and induce apoptosis during the progression of atherosclerosis [45]. Laffont [22] previously reported that platelet-derived microparticles containing miR-223Ago 2-complexes can regulate endothelial cell function. The increased level of miR-223 in platelet-derived exosomes suggested that this regulation may be mainly dependent on miR223. However, this hypothesis requires further investigation in vitro and in vivo.

Platelet-derived growth factor (PDGF) was first purified over 40 years ago as a serum factor that stimulates proliferation of arterial SMCs [46]. Studies on cardiovascular diseases show that PDGFR is expressed in all types of cells within atherosclerotic arterial walls; PDGFR $\alpha$ expression is increased in endothelium and macrophages, whereas PDGFR $\beta$ is primarily expressed in SMCs [47]. PDGFR $\beta$ is a predicted target of miR-223. In our miR-223 mimic transfection experiments, our results showed that miR-223 mimic can inhibit PDGFR $\beta$ expression in SMCs by $25 \%$. Our study showed that platelet-derived exosomes contain an increased level of miR-223 and that these exosomes reduced PDGFR $\beta$ expression in vitro by $32 \%$. Because both humans and mice share the same sequence for miR-233, the human platelet-derived exosome-mediated regulation of PDGFR $\beta$ expression in SMCs may be partly dependent on miR-223. And the exosomes had a greater inhibition on PDGFR $\beta$ expression may also dependent on other containing miRNAs and mRNA-regulatory-complex such as Ago 2 [22], these complexes may facilitate the PDGFR $\beta$ inhibition. Inhibition of PDGFR $\beta$ induced apoptosis in proliferating SMCs in vitro and balloon-injured arteries in vivo [48]. Shan's research showed that miR-223 had anti-proliferative and anti-migratory effects on SMCs; furthermore, they showed that overexpression of miR-223 enhanced SMC apoptosis [45].These studies were consistent with the results of our study showing that inhibition of PDGFR $\beta$ expression was associated with thrombosis and that platelet-derived exosomal miR-223 may trigger this phenomenon. Much of the cell proliferation response is mediated by the well-recognized MAPK signaling pathway [49]. PDGF substantially activate ERK2 in Ras-dependent manner [50]. To better understand this issue, further studies of whether the functions of platelet-derived exosomes are dependent on miR-223, as well as their molecular pathways and cell functions are required.

Previous studies showed that serotonin and thromboxane A2 stimulate plateletderived microparticles and induce SMC proliferation[51]. Our study investigated thrombinstimulated platelet-derived exosomes, and there were two differences between the two studies. First, the platelet agonist was different; second, the investigated extracellular vesicles were different. There was no discrepancy between these two studies. Furthermore, our study provided a new perspective regarding platelet-derived exosomes in SMCs. Thrombin stimulated platelet-derived exosomes inhibited PDGFR $\beta$ expression in SMCs. However, this finding requires further study to explain whether decreased PDGFR $\beta$ expression in SMCs can impair plaque stability and trigger the coagulation cascade.

\section{Study limitations}

This study was based on mouse models, and it is not clear whether the results regarding plasma exosomal miR-223, miR-339 and miR-21 levels can be applied in clinical practice requiring further investigation. The platelets used in this study were isolated from healthy volunteers, and may not reflect the conditions of atherosclerosis. 


\section{Cellular Physiology Cell Physiol Biochem 2016;38:2348-2365 \begin{tabular}{ll|l}
\cline { 2 - 2 } and Biochemistry $10.1159 / 000445588$ & $\begin{array}{l}\text { ( ) 2016 The Author(s). Published by S. Karger AG, Basel } \\
\text { www.karger.com/cpb }\end{array}$ \\
\hline
\end{tabular} Tan et al.: Platelet-Derived Exosomes as a Biomarker for Predicting Atherothrombosis}

\section{Conclusions}

Plasma exosomal miR-223, miR-339 and miR-21 levels were elevated before thrombus formation in an atherothrombotic mouse model, and thrombin-stimulated platelet-derived exosomes were enriched with these miRNAs. Platelet-derived exosomes could transfer the miRNAs into vascular SMCs and inhibit PDGFR $\beta$ expression in these cells. Meanwhile, arterial SMCs in thrombosis were also associated with decreased PDGFR $\beta$ expression compared with other atherosclerotic lesions. Our study provides information about a potentially novel signal transduction pathway from platelets to SMCs, as well as a potential biomarker for atherosclerosis.

\section{Sources of Funding}

This study was supported by the National Natural Science Foundation of China (No. 81541095; No. 81270288) and the Graduate Students Innovation Foundation of Peking Union Medical College (No. 10023-1002-1010).

\section{Acknowledgements}

We acknowledge the kind support of Pro. Yong Weidong and Deng Ran, Institute of Laboratory Animal Sciences, CAMS\&PUMC in the animal experiments. We thank Dr. Xu Fen and Dr. Ma Yi for proofreading this paper.

\section{Disclosures Statement}

None.

\section{References}

1 Finn AV, Nakano M, Narula J, Kolodgie FD, Virmani R: Concept of vulnerable/unstable plaque. Arterioscler Thromb Vasc Biol 2010;30:1282-1292.

2 Alfieri O, Mayosi BM, Park SJ, Sarrafzadegan N, Virmani R: Exploring unknowns in cardiology. Nat Rev Cardiol 2014;11:664-670.

3 Stone GW, Maehara A, Lansky AJ, de Bruyne B, Cristea E, Mintz GS, Mehran R, McPherson J, Farhat N, Marso SP, Parise H, Templin B, White R, Zhang Z, Serruys PW: A prospective natural-history study of coronary atherosclerosis. N Engl J Med 2011;364:226-235.

4 Arbab-Zadeh A, Fuster V: The myth of the "vulnerable plaque": transitioning from a focus on individual lesions to atherosclerotic disease burden for coronary artery disease risk assessment. J Am Coll Cardiol 2015;65:846-855.

$5 \quad$ Giri S, Jennings LK: The spectrum of thrombin in acute coronary syndromes. Thromb Res 2015;135:782787.

6 Weitz JI: Insights into the role of thrombin in the pathogenesis of recurrent ischaemia after acute coronary syndrome. Thromb Haemost 2014;112:924-931.

7 Martin JF, Kristensen SD, Mathur A, Grove EL, Choudry FA: The causal role of megakaryocyte-platelet hyperactivity in acute coronary syndromes. Nat Rev Cardiol 2012;9:658-670.

8 Sasaki T, Kuzuya M, Nakamura K, Cheng XW, Shibata T, Sato K, Iguchi A: A simple method of plaque rupture induction in apolipoprotein E-deficient mice. Arterioscler Thromb Vasc Biol 2006;26:1304-1309.

9 Clarke MC, Figg N, Maguire JJ, Davenport AP, Goddard M, Littlewood TD, Bennett MR: Apoptosis of vascular smooth muscle cells induces features of plaque vulnerability in atherosclerosis. Nat Med 2006;12:10751080. 


\section{Cellular Physiology Cell Physiol Biochem 2016;38:2348-2365 \begin{tabular}{l|l|l}
\hline DOI: 10.1159/000445588 & (c) 2016 The Author(s). Published by S. Karger AG, Basel
\end{tabular}

10 Chen YC, Bui AV, Diesch J, Manasseh R, Hausding C, Rivera J, Haviv I, Agrotis A, Htun NM, Jowett J, Hagemeyer CE, Hannan RD, Bobik A, Peter K: A novel mouse model of atherosclerotic plaque instability for drug testing and mechanistic/therapeutic discoveries using gene and microRNA expression profiling. Circ Res 2013;113:252-265.

11 Caro CG: Discovery of the role of wall shear in atherosclerosis. Arterioscler Thromb Vasc Biol 2009;29:158161.

12 Slager CJ, Wentzel JJ, Gijsen FJ, Thury A, van der Wal AC, Schaar JA, Serruys PW: The role of shear stress in the destabilization of vulnerable plaques and related therapeutic implications. Nat Clin Pract Cardiovasc Med 2005;2:456-464.

13 Landry P, Plante I, Ouellet DL, Perron MP, Rousseau G, Provost P: Existence of a microRNA pathway in anucleate platelets. Nat Struct Mol Biol 2009;16:961-966.

14 Dangwal S, Thum T: MicroRNAs in platelet biogenesis and function. Thromb Haemost 2012;108:599-604.

15 Edelstein LC, McKenzie SE, Shaw C, Holinstat MA, Kunapuli SP, Bray PF: MicroRNAs in platelet production and activation. J Thromb Haemost 2013;11:S340-350.

16 Osman A, Falker K: Characterization of human platelet microRNA by quantitative PCR coupled with an annotation network for predicted target genes. Platelets 2011;22:433-441.

17 Willeit P, Zampetaki A, Dudek K, Kaudewitz D, King A, Kirkby NS, Crosby-Nwaobi R, Prokopi M, Drozdov I, Langley SR, Sivaprasad S, Markus HS, Mitchell JA, Warner TD, Kiechl S, Mayr M: Circulating microRNAs as novel biomarkers for platelet activation. Circ Res 2013;112:595-600.

18 Colombo M, Raposo G, Thery C: Biogenesis, secretion, and intercellular interactions of exosomes and other extracellular vesicles. Annu Rev Cell Dev Biol 2014;30:255-289.

19 Hoefer IE, Steffens S, Ala-Korpela M, Back M, Badimon L, Bochaton-Piallat ML, Boulanger CM, Caligiuri G, Dimmeler S, Egido J, Evans PC, Guzik T, Kwak BR, Landmesser U, Mayr M, Monaco C, Pasterkamp G, Tunon J, Weber C: Novel methodologies for biomarker discovery in atherosclerosis. Eur Heart J 2015;14;36:26352642.

20 Aatonen MT, Ohman T, Nyman TA, Laitinen S, Gronholm M, Siljander PR: Isolation and characterization of platelet-derived extracellular vesicles. J Extracell Vesicles 2014;3: doi: 10.3402/jev.v3.24692. eCollection 2014.

21 Arraud N, Linares R, Tan S, Gounou C, Pasquet JM, Mornet S, Brisson AR: Extracellular vesicles from blood plasma: determination of their morphology, size, phenotype and concentration. J Thromb Haemost 2014;12:614-627.

22 Laffont B, Corduan A, Ple H, Duchez AC, Cloutier N, Boilard E, Provost P: Activated platelets can deliver mRNA regulatory Ago2*microRNA complexes to endothelial cells via microparticles. Blood 2013;122:253261.

23 Gambim MH, do Carmo Ade O, Marti L, Verissimo-Filho S, Lopes LR, Janiszewski M: Platelet-derived exosomes induce endothelial cell apoptosis through peroxynitrite generation: experimental evidence for a novel mechanism of septic vascular dysfunction. Crit Care 2007;11:R107.

24 Uryga AK, Bennett MR: Ageing induced vascular smooth muscle cell senescence in atherosclerosis. J Physiol 2015;15;594:2115-2124.

25 Silverman-Gavrila R, Silverman-Gavrila L, Bendeck MP: Cell division fidelity is altered during the vascular response to injury: its novel role in atherosclerosis progression. Am J Pathol 2013;182:628-639.

26 Bauriedel G, Hutter R, Welsch U, Bach R, Sievert H, Luderitz B: Role of smooth muscle cell death in advanced coronary primary lesions: implications for plaque instability. Cardiovasc Res 1999;41:480-488.

27 Golovina VA, Blaustein MP: Preparation of primary cultured mesenteric artery smooth muscle cells for fluorescent imaging and physiological studies. Nat Protoc 2006;1:2681-2687.

28 Roucourt B, Meeussen S, Bao J, Zimmermann P, David G: Heparanase activates the syndecan-syntenin-ALIX exosome pathway. Cell Res 2015;25:412-428.

29 Vlachos IS, Paraskevopoulou MD, Karagkouni D, Georgakilas G, Vergoulis T, Kanellos I, Anastasopoulos IL, Maniou S, Karathanou K, Kalfakakou D, Fevgas A, Dalamagas T, Hatzigeorgiou AG: DIANA-TarBase v7.0: indexing more than half a million experimentally supported miRNA:mRNA interactions. Nucleic Acids Res 2015;43:D153-159.

30 Huang da W, Sherman BT, Lempicki RA: Systematic and integrative analysis of large gene lists using DAVID bioinformatics resources. Nat Protoc 2009;4:44-57. 


\section{Cellular Physiology Cell Physiol Biochem 2016;38:2348-2365

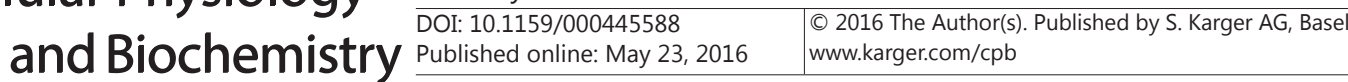 \\ Tan et al.: Platelet-Derived Exosomes as a Biomarker for Predicting Atherothrombosis}

31 Motoyama S, Ito H, Sarai M, Kondo T, Kawai H, Nagahara Y, Harigaya H, Kan S, Anno H, Takahashi H, Naruse H, Ishii J, Hecht H, Shaw LJ, Ozaki Y, Narula J: Plaque Characterization by Coronary Computed Tomography Angiography and the Likelihood of Acute Coronary Events in Mid-Term Follow-Up. J Am Coll Cardiol 2015;66:337-346.

32 Libby P, Pasterkamp G: Requiem for the 'vulnerable plaque'. Eur Heart J 2015;36:2984-2987.

33 Rittersma SZ, van der Wal AC, Koch KT, Piek JJ, Henriques JP, Mulder KJ, Ploegmakers JP, Meesterman M, de Winter RJ: Plaque instability frequently occurs days or weeks before occlusive coronary thrombosis: a pathological thrombectomy study in primary percutaneous coronary intervention. Circulation 2005;111:1160-1165.

34 Newby AC, George SJ: Proliferation, migration, matrix turnover, and death of smooth muscle cells in native coronary and vein graft atherosclerosis. Curr Opin Cardiol 1996;11:574-582.

35 Alexander MR, Owens GK: Epigenetic control of smooth muscle cell differentiation and phenotypic switching in vascular development and disease. Annu Rev Physiol 2012;74:13-40.

36 Strony J, Beaudoin A, Brands D, Adelman B: Analysis of shear stress and hemodynamic factors in a model of coronary artery stenosis and thrombosis. Am J Physiol 1993;265:H1787-1796.

37 Mailhac A, Badimon JJ, Fallon JT, Fernandez-Ortiz A, Meyer B, Chesebro JH, Fuster V, Badimon L: Effect of an eccentric severe stenosis on fibrin(ogen) deposition on severely damaged vessel wall in arterial thrombosis. Relative contribution of fibrin(ogen) and platelets. Circulation 1994;90:988-996.

38 Morrow DA, Braunwald E, Bonaca MP, Ameriso SF, Dalby AJ, Fish MP, Fox KA, Lipka LJ, Liu X, Nicolau JC, Ophuis AJ, Paolasso E, Scirica BM, Spinar J, Theroux P, Wiviott SD, Strony J, Murphy SA: Vorapaxar in the secondary prevention of atherothrombotic events. N Engl J Med 2012;366:1404-1413.

39 Mega JL, Braunwald E, Wiviott SD, Bassand JP, Bhatt DL, Bode C, Burton P, Cohen M, Cook-Bruns N, Fox KA, Goto S, Murphy SA, Plotnikov AN, Schneider D, Sun X, Verheugt FW, Gibson CM: Rivaroxaban in patients with a recent acute coronary syndrome. N Engl J Med 2012;366:9-19.

40 Coughlin SR: Thrombin signalling and protease-activated receptors. Nature 2000;407:258-264.

41 Esmon CT, Fukudome K, Mather T, Bode W, Regan LM, Stearns-Kurosawa DJ, Kurosawa S: Inflammation, sepsis, and coagulation. Haematologica 1999;84:254-259.

42 Jansen F, Yang X, Proebsting S, Hoelscher M, Przybilla D, Baumann K, Schmitz T, Dolf A, Endl E, Franklin BS, Sinning JM, Vasa-Nicotera M, Nickenig G, Werner N: MicroRNA expression in circulating microvesicles predicts cardiovascular events in patients with coronary artery disease. J Am Heart Assoc 2014;3:e001249.

43 Zampetaki A, Willeit P, Tilling L, Drozdov I, Prokopi M, Renard JM, Mayr A, Weger S, Schett G, Shah A, Boulanger CM, Willeit J, Chowienczyk PJ, Kiechl S, Mayr M: Prospective study on circulating MicroRNAs and risk of myocardial infarction. J Am Coll Cardiol 2012;60:290-299.

44 Schulte C, Molz S, Appelbaum S, Karakas M, Ojeda F, Lau DM, Hartmann T, Lackner KJ, Westermann D, Schnabel RB, Blankenberg S, Zeller T: miRNA-197 and miRNA-223 Predict Cardiovascular Death in a Cohort of Patients with Symptomatic Coronary Artery Disease. PLoS One 2015;10:e0145930.

45 Shan Z, Qin S, Li W, Wu W, Yang J, Chu M, Li X, Huo Y, Schaer GL, Wang S, Zhang C: An Endocrine Genetic Signal Between Blood Cells and Vascular Smooth Muscle Cells: Role of MicroRNA-223 in Smooth Muscle Function and Atherogenesis. J Am Coll Cardiol 2015;65:2526-2537.

46 Ross R, Glomset J, Kariya B, Harker L: A platelet-dependent serum factor that stimulates the proliferation of arterial smooth muscle cells in vitro. Proc Natl Acad Sci U S A 1974;71:1207-1210.

47 Karvinen H, Rutanen J, Leppanen O, Lach R, Levonen AL, Eriksson U, Yla-Herttuala S: PDGF-C and -D and their receptors PDGFR-alpha and PDGFR-beta in atherosclerotic human arteries. Eur J Clin Invest 2009;39:320-327.

48 Liu B, Han M, Sun RH, Wang JJ, Liu YP, Wen JK: Acetylbritannilactone induces G1 arrest and apoptosis in vascular smooth muscle cells. Int J Cardiol 2011;149:30-38.

49 Bornfeldt KE, Campbell JS, Koyama H, Argast GM, Leslie CC, Raines EW, Krebs EG, Ross R: The mitogenactivated protein kinase pathway can mediate growth inhibition and proliferation in smooth muscle cells. Dependence on the availability of downstream targets. J Clin Invest 1997;100:875-885.

50 Page K, Li J, Hershenson MB: Platelet-derived growth factor stimulation of mitogen-activated protein kinases and cyclin D1 promoter activity in cultured airway smooth-muscle cells. Role of Ras. Am J Respir Cell Mol Biol 1999;20:1294-1302.

51 Pakala R: Serotonin and thromboxane A2 stimulate platelet-derived microparticle-induced smooth muscle cell proliferation. Cardiovasc Radiat Med 2004;5:20-26. 